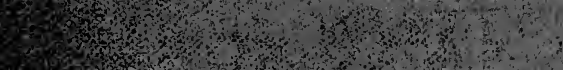

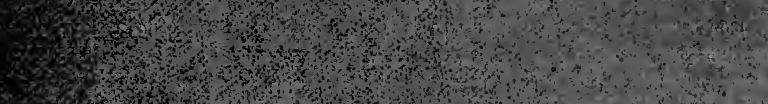

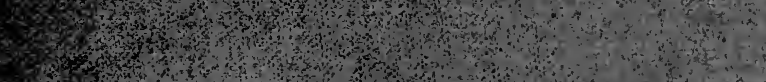

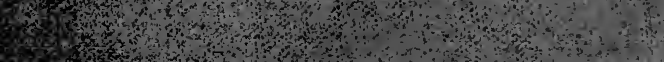

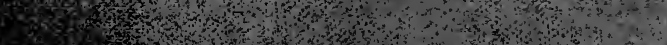

10.

6.

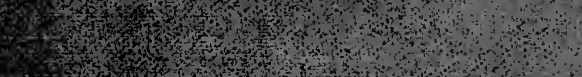

(1) 5 (n)

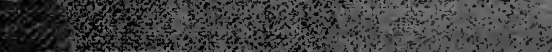

36 .

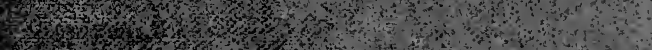

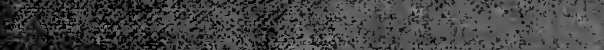

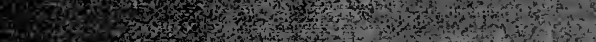

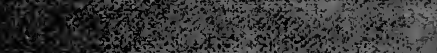

4.

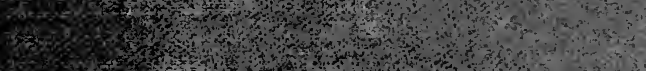

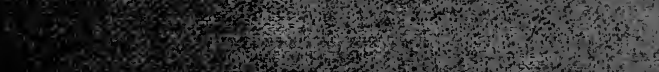
6.

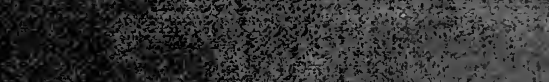

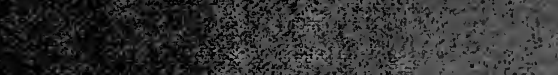

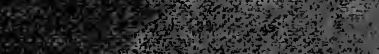

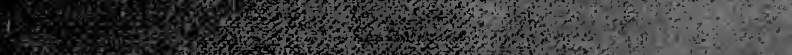

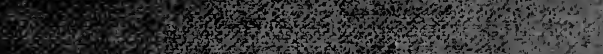

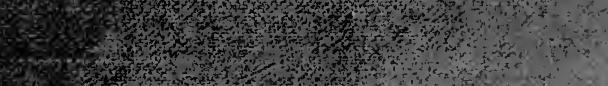

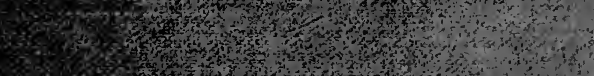

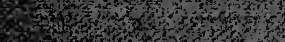

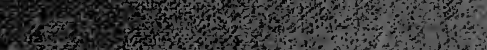

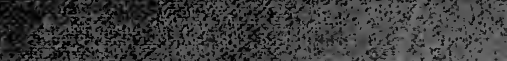



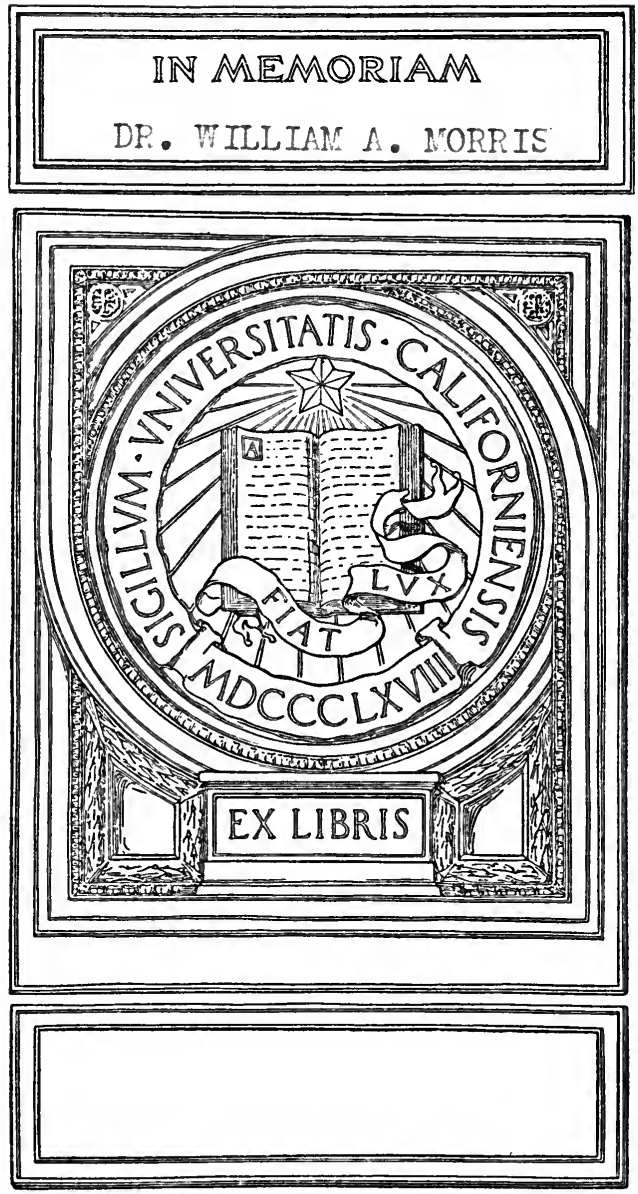
Mts. a. Mormis.

London

gune 26,1923. 


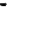




\section{THE IMPERIAL CONFERENCE OF IgII FROM WITHIN}




\section{Digitized by the Internet Archive in 2007 with funding from Microsoft Corporation}




\title{
THE IMPERIAL
}

\section{CONFERENCE OF I 9 I I} FROM WITHIN

\author{
BY THE HON. \\ SIR JOHN G. FINDLAY \\ K.C.M.G., K.C., LL.D. \\ ATTORNEY-GENERAL OF NEW ZEALAND
}

(A REPRESENTATIVE OF NEW ZEALAND AT THE IMPERIAL CONFERENCE, I 9 I 1 )

\section{LONDON}

CONSTABLE \& COMPANY, LTD.

I 9 I 2 


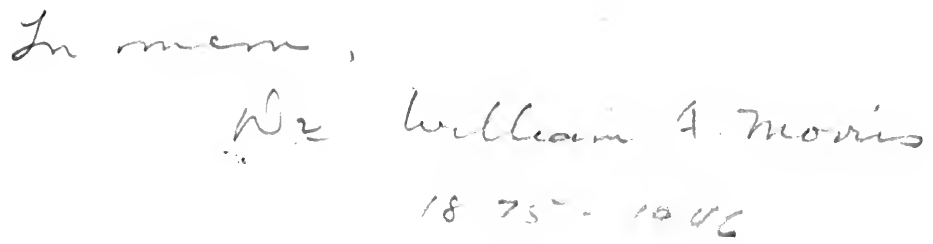

Richard Clay \& Sons, Limited,

HRONAWICK ATREET, STAMFORD STREET, S.\&.

AND BUNGAY, GUFFOLK. 


\section{$J N_{216}$ \\ $F_{5}$}

\section{PREFACE}

THE first chapter of this book containing, as it mainly does, short personal sketches of several of those members of the present British Cabinet who took part in the last Imperial Conference, is chiefly intended for Colonial readers, to whom I have hoped to convey some definite impressions of the personality of men whom they have never seen, but of whose acts and utterances they read so much.

My explanation and criticism of the methods of the Conference, and of the work it did, will be found in the second and third chapters.

In the fourth chapter, which, it will be seen, comprises the major portion of the book, I have dealt somewhat fully with the proposal New Zealand made at the Conference for a Representative Imperial Council, and with the attitude of the present British Government towards that proposal. In this connection I have attempted to state 
the case for Imperial Federation from the point of view of its numerous advocates in the Oversea Dominions.

The title this book bears is not intended to imply that its pages contain any information which has not been already published, but merely to give point to the fact that the writer had the great advantage of being present as a representative of New Zealand throughout the sittings and discussions of the Conference. 


\section{CONTENTS}

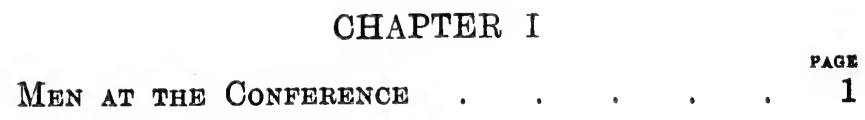

CHAPTER II

Methods OF Work . . . . . . . 31

\section{CHAPTER III}

Matters dealt with . . . . . . 40

\section{CHAPTER IV}

New Zealand's Proposal and Imperial FederaTION 


\section{THE IMPERIAL CONFERENCE OF 1911 FROM WITHIN}

\section{CHAPTER I}

MEN AT THE CONFERENCE

As office in Downing Street was once and for many years in British history the seat and centre of government for all the Colonial Empire. How much Downing Street knew of its Dominions even in later days is illustrated by the story told of Lord Palmerston, who when in office solved some difficulty in appointing a new Colonial Secretary by saying, "Well, I'll take the Colonies myself," and then, turning to a permanent official, requested him to "just come upstairs and show me on the map where these $\mathrm{d}-\mathrm{d}$ places are."

The Motherland long followed Roman methods in dealing with her possessions 
oversea, and the records of this Colonial control are largely a history of blunder, arrogance and indifference. But the old order changeth, and, strangely enough, "an office in Downing Street" was, on the 23rd day of May, 1911, made the witness of the most striking symbol of its own dethronement-for it was in "an office in Downing Street" that the first meeting of an Imperial Conference was held-a meeting which made visible and palpable the fact that Colonial autonomy was now fully and finally admitted by the Imperial Government. It was the Prime Minister of England himself-the President of the Conference-who emphasised this change and declared that the local autonomy of Britain's daughter nations was now "absolute, unfettered and complete" - slowly developed to completion as the former sense of submission to a central authority had given place to "loyalty to a common head and to a co-operation spontaneous and unforced for common interests and purposes." These were some of the words, and this the spirit, in which the Oversea representatives were welcomed by the man officially best entitled to speak for the Motherland. It is not my intention to discuss the stages of this change. I shall 
not dwell upon the significance in our Empire's history of the institution of these Conferences or upon the new Imperial relationship they imply. But, lest this declaration of Mr. Asquith's may seem rather rhetorical and suggestive of admitting children somewhat prematurely to a share in the household control, let us consider some Imperial proportions. The Empire contains $11,908,378$ square miles of territory -an area better conceived by remembering that it is, for example, more than three times that of the United States with all its exterior possessions thrown in, and three times the size of the Chinese Empire, enormous though it is. Britain holds, in fact, one-fifth of the whole land surface of the globe, and of these boundless territories, how much is occupied and controlled by the self-governing Dominions represented at this first Imperial Conference? An area of seven and a quarter million square miles. So that when the British Prime Minister generously welcomed the representatives of Canada, Australia, New Zealand, South Africa and Newfoundland, as co-trustees with the Motherland in Imperial control, he was addressing those whose countries possessed an area equal to three-fifths of

B 2 
the Empire, and a total white population of not less at this moment than 14,500,000.

These figures dispel any hazy ideas that children are being prematurely admitted to a share in the household control, and the relationship so clearly expressed by Mr. Asquith becomes still more natural and reasonable when it is remembered that in a comparatively few years these young nations will exceed the Motherland in numbers, in vigour, and even in wealth. Such reflections are not here irrelevant since they give additional weight and significance to this first Imperial Conference. They divest it-even for the most cynical or facetiousof any Gilbertian aspect. They silence the feeble pleasantry that the system is a device " to amuse young children and keep them good." They help us to realise the momentous fact that the Empire has now actually entered upon a new and critical phase from which may issue either a great Imperial federation, or (if the Dominions continue to grow, as they are now rapidly growing, populous and powerful without organised union) a disintegration of the Empire into a number of unrelated independent and Sovereign States. This, however, is a topic I shall deal with later and I do not wish 
to pursue it further here. I have touched upon it mainly to mark the paradox-surely a picturesque one-of a gathering of Colonial Ministers for Imperial purposes in "an office in Downing Street."

There were present thirteen Oversea and two British Ministers, and these included (with Mr. Asquith) six Premiers. The British Press referred to the meeting as that of "a Cabinet of Cabinets"-a figure of speech to which England's Prime Minister lent colour by commencing his opening address of welcome with the words : "Gentlemen and Colleagues." But if it could not be fitly described as a Cabinet of Cabinets, it was certainly a family gathering for business purposes-John Bull \& Sons discussing proposals for improving the co-operation and co-relation between the branches and the chief establishment. Mr. Asquith, indeed, who was in the chair as head of the house, is himself in face and figure reminiscent of Punch's best representations of John Bull. Thick set, strongly built, heavy of feature, with an habitual look of determination-some people would call it dogged and some stolid-he would be a noticeable and remarkable"man in"any company. Throughout the many daily sittings of the Conference 
its members had ample opportunity to recognise those outstanding qualities of his character which have raised him to one of the most powerful positions in the world. In intellectual force and grasp-in brain power -he has few equals in England. What he does-even if the task be great or difficulthe performs with an ease that discloses not so much an effort as an unlimited reserve of power of which the performance at the moment is but a small example. You see a logical athlete achieving his fine feats with a surprising air of ease and confidence. In early briefless days he wrote for the Economist, and this practice, added to an intellect clear, keen and coldly practical, has made him in thought and speech that exact man of whom Bacon speaks. There is no rhetorical embroidery. The stream of his ideas never loses itself in wordy sands, however glittering, but runs smoothly on between well-defined continuous banks in the directest course to its destination. His is not a mathematical terseness which calls for a concentrated attention beyond the faculty of most audiences, but rather an aptness, expressiveness and simplicity of speech which enables you to perceive his meaning as a plain, well-fitting dress enables 
you the more readily to recognise the wearer. But it is not the choice or economy of his words which impresses a hearer so much as the orderly arrangement of his ideas. There is an almost mechanical precision in his methods of developing an argument. Its parts seem to fall into their places with the metallic regularity and certainty of the operations of a linotype. He is one of the finest debaters in England-an intellectual force without a superior in the House of Commons; but when all this is said it must nevertheless be admitted that he has less personal magnetism about him than any of the leading public men in Great Britain. He cannot be called a popular figure. $\mathrm{He}$ owes his success to the qualities of his brain, not to those of his heart. He seems never to divest himself of a mantle of mental aloofness. He does not shake you by the hand-you rather shake his, while he wears an air of abstraction which leaves you in doubt as to whether he is not going through the courtesy unconsciously. He clearly is not voluntarily resisting any warmth of feeling. It is not an intentional austerity -it is constitutional; it is not a pose, but a fact. His demeanour does not seem to alter with the importance of the man 
he is addressing. He to all men best seems the thing he is. A strong intellectual character untouched by - or at least betrayingnone of the emotions and feelings of the common heart of our humanity-a fine mental gymnast who in his best turns seems to feel neither inspiration nor perspiration. Such qualities have their corresponding defects. Most of the great movements which have furthered the cause of progress and humanity have been born, not in the head, but in the heart. It is the heart which has always provided the necessary combination of enthusiasm, devotion and energy as the only breeze that can fill the canvas of a great new idea. Sentiment plays a very minor part in Mr. Asquith's outlook upon public life. $\mathrm{He}$ is not stirred by large emotions like Mr. Lloyd George. He must be an incomparable guide and adviser in Cabinet. Cool, careful, sagacious and alert-

"A daring pilot in extremity,

Pleased with the danger when the waves run high,"

but he is a pilot who steers only by the authorised chart and in charted seas. $\mathrm{He}$ will not willingly trust his barque to an unexplored ocean under the guidance of 
the stars. He is never likely to originate any great, bold or novel reform, although, should it ultimately secure his approval, he will support it with his splendid advocacy. These qualities and defects are commonly found in company. The intellect is naturally conservative, as Bright pointed out when he referred to the two great English Universities as the stronghold " of dead languages and never-dying prejudices." Intellectual methods and consideration, if pursued exclusively in connection with schemes of human progress, produce a distrust of new experiments-an excessive caution. Mr. Asquith, however, has no "craven scruple of thinking too precisely on the event which hath but one part wisdom and ever three parts coward." It is with him not fear, but a constitutional dislike of new departures from the tried and beaten way of the past. A strong, safe, able man-one of the ablest in England-but never likely to be stirred by any large new gospel of human progress or by Gladstone's lofty aspirations for a truer social justice.

In the occasional absence of Mr. Asquith, Mr. Lewis Harcourt, who was present at every meeting, presided. He, indeed, as Colonial Secretary, was the British Minister 
with whom we had most to do-with whom we were naturally brought into closest intimacy. As Sir Wilfrid Laurier pointed out in moving a complimentary resolution, the heaviest and most difficult part of the work of the Conference fell upon Mr. Harcourt's shoulders-that of studying, mastering, classifying and preparing for discussion the various questions which came up for consideration-and this in addition to participation in the deliberations which sought their solution. Mr. Harcourt was appointed Colonial Secretary comparatively recently, and with the duties of his new office might fairly be considered somewhat unfamiliar; but few men in public life in England have had so long and so thorough an apprenticeship for ministerial office of every kind as he. I met him nine years ago, then as always for some twenty years the devoted companion and associate of his fatherthe late Sir William Vernon Harcourt. It is well known that he prepared with untiring thoroughness much of his father's ministerial work-a devotion which absorbed the most vigorous years of his life, because it was not until he was over forty that he entered Parliament. But such genuine, honest, unseen work is repaid in the best way and by 
the best of all rewards. It makes solid additions to the equipment, qualifications and character of the worker. Probably most of us saw as much of Mr. Harcourt in private interview as in open conference, and while one's first impression of him is that he has more suavity of manner than depth or force of character, one's last impression is that he is a man of infinite penetration, tact and resource. Only towards the close of the Conference did I detect with what an undisclosed but masterly adroitness he had handled its members and influenced the conclusions of their deliberations. $\mathrm{He}$ moves towards his purpose calmly, slowly, without the least bit of anxiety, but rather with a hint of careless indifference, and thus achieves his purpose so quietly and unostentatiously that it seems rather to have happened naturally than to have been designed. It is said that he has the "grand manner." He certainly preserves unfailingly that attitude of natural confidence and repose which marks the best type of Englishman. He is, I think, an incomparable judge of mentesting their metal and deciding their weight with the ease and smoothness of a machine, while he himself remains as inscrutable behind his easy manners and refined suavity 
as the noumena behind phenomena. $\mathrm{He}$ is not an orator-I should not think he is even a good platform speaker-for to be that necessitates a demonstrativeness in words, action and feeling which is foreign to his nature and bearing. His delivery when addressing a large general audience is slow and rather monotonous. The matter of his speeches, however, is excellent. It is not veneered, but solid right through. There is none of the nine-carat politician about him. The whole metal is genuine. His style, as one would expect from his lineage, has none of the cheap splendours of thinskinned, dubious jewelry-it is not decorative, but dignified, finished and graceful. Above all other qualities he seems to have that of generalship-of strategy governed by the best rules of the game. He must, it is generally admitted, be counted as one of the few younger Ministers to whom the highest public position in England is possible. Meanwhile, and as long as he is Colonial Secretary, his industry, tact and judgment will do much to improve the relations between the Motherland and her Dominions oversea. Whether he believes in, or desires some definite system of, Imperial Federation one cannot say, for he does not volunteer 
any statement of his convictions upon such matters. He has great gifts of discreet reticence and a self-command which seems imperturbable. Of this, at any rate, we may be sure-there will be no friction between the Colonial Governments and the Colonial Office while he is Colonial Secretary, and that he will lose no opportunity to tighten and, where possible, create the true ties of Empire is equally certain.

Upon different days, when topics (within the Departments of special British Ministers) were being discussed, these Ministers took a seat in the Conference. Owing to this arrangement we were privileged to hear and be associated on different days with Mr. Lloyd George, the Lord Chancellor, Sir Edward Grey, Lord Haldane, Mr. Winston Churchill, Lord Crewe, Mr. John Burns, Mr. Buxton, Mr. Herbert Samuel, Sir Rufus Isaacs and Sir John Simon. This was, indeed, almost the whole British Cabinet with the exception of Lord Morley. Every one of these Ministers impressed us not only with his ability and lucidity of speech, but with the grasp and knowledge of the matter in hand. It seems, if I may venture the opinion, that the British Cabinet to-day contains a larger number of men of first-rate 
ability than it has done at any time in England's history-certainly this Ministry cannot be challenged in respect of power and attainments by the historical "Ministry of all the talents." Of all this list of brilliant men, the two who impressed me most were Sir Edward Grey and Mr. Lloyd George. No man who heard him in that Conference will ever forget Sir Edward Grey's address to us on the history and present nature of the Foreign policy of Great Britain. It was delivered to us sitting as a Secret Committee of Defence. It impressed even those who already knew all that could be told, for Mr. Asquith called it "a thing which will be stamped upon all our recollections," and added, "I do not suppose there is one of us who did not feel when that exposition of our foreign relations had been concluded that we realised in a much more intimate and comprehensive sense than we had ever done before the international position and its bearings upon the problems of Government in the different parts of the Empire." But it was not what we were told-impressive and profoundly interesting though it was-that engraved itself most vividly and permanently on our minds and memories; it was the man, his manner, and his pro- 
found sincerity. No face in public life to-day combines spirituality with the features of power and grace so perfectly as his. It is reminiscent of the best Greek sculpture. Finely chiselled, statuesque in its calm, and yet animated by an expression in lips and eyes of radiant sincerity. He began by intimating that he proposed to lay before us all-everything there was to tell-of the history and lines of the Foreign policy of Great Britain, and that he felt no doubt that his confidence would be followed on our part by a sense of the honourable obligations of reticence it necessarily imposed. Then, for over an hour, he told the story of our foreign relationship with a masterly grasp of his subject - with a dignified and simple eloquence made the more impressive by his clear, well-modulated voiceand with a frankness and unreserve that appealed to the heart as well as to the understanding. That speech-with its power, sincerity and truthfulness-did more to stir and leave a sense of Imperial unity in our blood than all the rest that happened or was said throughout the Conference. But the man impressed us more than his words; and the figure, the features, and the voice that expressed it will remain a 
more vivid memory than even the speech itself.

Mr. Lloyd George was present as Chancellor of the Exchequer, but had not in that capacity any occasion to make important addresses or, indeed, say anything that could properly be called an address. Nevertheless, we saw a good deal of him, for he was present on more than one occasion, and I met him informally at several private interviews. Moreover, I heard him making important speeches in his place in Parliament. $\mathrm{He}$ is probably the most interesting figure in the public life of England to-day. At once the most admired and the most hated. Of this I saw an illustration on the day following the Coronation, when London had gathered in the streets to see the Royal Procession. On one side of a square near the Houses of Parliament was the Peers' stand, filled to overflowing with peers and their friends; below were the streets packed with the humblest of commoners-the line of the procession being kept clear by soldiers and policemen. Shortly before the advance guard of the procession reached this spot, Mr. Lloyd George-a little girl's hand in his-walked slowly down between these lines of men in red and blue to his seat in a stand 
further on. He was greeted with groans from some occupants of the Peers' stand, and instantly a cheer rose from the crowded pavements-increasing as the groans increased-until it seemed to become a vocal contest between the people of the pavement and the stand. Mr. Lloyd George walked on with that elastic youthful gait of his, so expressive of his nature and disposition. He smiled good-naturedly to left and right, and, sweeping the Peers' stand with a look of hearty amusement and gaiety, passed on to his place.

It is not his humble origin and meteoric rise that make him such a fascinating figure-although the picture of the old uncle, local preacher and bootmaker, coaching the fatherless Welsh lad in the elements of Latin as a preparation for the law, lives in the minds of the British people. What the British people love above all else in a man is the fighter-is the quality of moral courage; and he is a man who knows not fear. Whether it was leading a revolt at schoolan attack upon the cemetery gates that exclude the body of an old dissenter-that grim hour at Birmingham during the Boer War when his life was in the gravest peril from a frenzied mob-whether it was in 
these hours of daring or in many another situation demanding intrepidity in his public career he has always shown himself one of the dauntless souls. $\mathrm{He}$ is a Celt, but his is not the blind or reckless hardihood of the Celt. Like Banquo, "much he dares, and to that dauntless temper of his mind he hath a wisdom that guides his valour to act in safety." He is one of the men to whom, I believe, politics is essentially a gospel and not a game. He is a man with a mission. With him it is "the Cause"-the cause first and the guerdon of popularity and glory afterwards, if it comes through the promotion of the cause. $\mathrm{He}$ is the disciple of no political school of thought. He is not cribbed, cabined, confined or bound in by saucy doubts and fears springing from economic formulæ and doctrinaire principles. He has been in the fighting line since he entered Parliament, and borne more than his share of the heat and burden of the day. Years, with their weight of work and responsibility, have begun to somewhat ashen his hair and "transfix the flourish set on youth;" but there is no languor in his heart, no weakness in his word, no weariness on his brow. He seems to carry eternal summer in his soul, and his laugh 
and manner have all the spontaneity and freshness of a boy. No man, I was told, was more personally popular in the House of Commons, and certainly it seems safe to say that no man is more widely and intensely popular with the masses of the people of England. He counts for more in the future of British politics than any other mannot mainly from his intellectual or oratorial qualities-for he is not the equal of Mr. Asquith in intellectual grasp and power. He has not that splendid reserve of strength - that unfailing control of the right word, the expressive phrase, that command of stately lucidity, which distinguish the Prime Minister above other men; he is not Mr. Winston Churchill's equal as a Parliamentary speaker, nor has he Sir Edward Grey's lofty impressive personality. But he has fixity and sincerity of purpose-he feels his politics as perhaps no other British Minister save Sir Edward Grey does, and it is from his heart he gets that courage and enthusiasm with which he tackles such desperate problems as that of his Insurance Bill. He can be adroit and elusive where necessary, but his style is marked by a frankness which is very fascinating and disarming. We pressed upon him the iniquity of the existC 2 
ing system of double taxation under which a man resident in London, who makes his whole income in one of the Colonies, is taxed fully on its amount both in England and in the land where the income is made. He did not attempt to defend this upon any broad or fine-spun principles of justicehe made no effort to cloud the issue and so escape our point-he simply frankly told us how many millions the British Exchequer would lose by the concession we asked, and said : "Gentlemen-we cannot afford it, and on that ground alone it is useless to discuss the matter further." It is this spirit of courageous frankness which wins him so many friends and so much loyal support. It is constitutional with himnot mere policy. But while a score of qualities mark him out for leadership, his friends contemplate such a contingency with some uneasiness. He has the impulsiveness of the Celtic temperament. Naturally a tender-hearted man, he is, on the one hand, rather too fond of concession as an act of grace, while on the other, under sufficient provocation or from some fervent devotion to a particular principle, he will resist compromise to the point of obstinacy. His present leader himself touched upon some 
of these features of his colleague's character in a speech delivered some time ago, when he said : "He is a man of sympathetic nature-sometimes I am disposed to think he is almost of too impressionable a nature when appeals of this kind (for a concession) are addressed to him." Under Mr. Asquith, who is the embodiment of unemotional sober judgment and sagacity-one "wise to know the limits of resistance and the bounds determining concession "-Mr. Lloyd George has been largely protected from the defects of his qualities. But should the day come when his hand must take the helm, that daring impetuosity, impressionableness and occasional unwise resistance-that mixture of qualities or some of them-may lead to the political maelstrom. But who can tell? He has in the past risen to his responsibilities with splendid courage and self-mastery, and he may have the power, should the need arise, of subduing his constitutional weaknesses to the necessities of the highest office.

Perhaps the most striking situation in the course of the Conference was seen during the days the Foreign policy and the defences of the Empire were under review. Not only Sir Edward Grey, but Lord Haldane, 
the Minister for War, and Mr. McKenna, First Lord of the Admiralty, addressed usunfolding Britain's foreign policy, her naval and military programmes, and the strong and weak points in our defences. All this, of course, at secret sittings. At the table sat Lord Kitchener, Sir John French and other men famous in the Boer War; and, as it happened, opposite to them sat BothaGeneral Botha. How the whirligig of time brings in its revenges! We recall Colenso, Spion Kop, Belfast, Dalmanutha and a dozen other conflicts on the veldt, some ten or eleven years ago, when Botha, as Commander of the Boer forces, showed what courage, resource and military genius he possessed. The resolute, active, dauntless, elusive foe of England-now he sits in this Secret Council listening to the arcana of the War Office and the Admiralty. After one has realised-and it requires some effort -the full significance of this and the magnificent and enduring proof it establishes of British manliness and magnanimity-he will next admit that the man in question was worthy of this trust and confidence. Here was not only the greatest Boer General of the war, but the leading spirit and guiding mind of the Boers since the war; the man 
to whom peace was due more than to any other, and to whom South Africa, in large measure, owes the Union it has so splendidly and rapidly achieved. Some of the most interesting of my memories are the frequent talks I had with him at the Hotel Cecil, where we Oversea representatives all stayed. He impresses one at once as a strong, resolute man, with that simplicity of manner and modesty of nature we always like to find associated with greatness-without which, indeed, true greatness is seldom found. $\mathrm{He}$ talked much of the war, without bitterness, but in a tone of sorrow and regret. The moving accidents by flood and field which he now and then quietly narrated did not circle round the third vowel. His conversation is in this respect strikingly impersonal. It has, moreover, the directness of strength. Sophistry and verbal tricks with veracity are not found in it. In the company of some men, it has been said, we occasionally feel our instinct for right and wrongfor truth and falsehood-being blurred or blunted. Here is a man, however, who seems to provide Tennyson's ideal-

"Ah, God, for a man with a heart, head and hand Like some of the simple great ones gone For ever and ever by, 
One still strong man in a blatant land Whatever they call him, what care IAristocrat, Democrat, Autocrat, one Who can rule, and dare not lic."

His sincerity is constitutional. It is the basis of his nature. It strikes one as the fruit and native growth of his great strength and courage. For sincerity, although often absent from men of boisterous daring, is seldom wanting in strong men of silent fearlessness. Only once in our conversation did he speak of the war with bitter warmth, and that was when his resolute opposition to it was mentioned. "My courage, my loyalty to my race, were impugned in the Transvaal Councils because I urged the disparity of the odds-the hopelessness of ultimate victory; because I foretold what must, and did happen-impugned by men recklessly clamorous for war, and, worst of all, in some instances, by men who, when the tide turned overwhelmingly against us, changed sides and fought us in the British lines." His face darkened as he said, "That is to me the bitterest memory of the war." He must have been a man of iron will and physical constitution. A farmer by calling, he had spent his life mainly in the open and learnt the trade of war-defending life and 
home in those earlier contests with the native tribes of South Africa. But no human endurance could undergo without physical debilitation the ordeal of exposure, hunger and exhaustion which his determined, dauntless will so often imposed upon him during that pathetic struggle. His colleagues sometimes spoke of this; but it was a topic upon which he himself was silent. The traces of this ordeal are there, however, and while he still seems to possess an iron frame, the brunt of those nights and days is now recalled in not unfrequent hours of sleeplessness and pain.

He was, I think, the most popular visitor to England. None, on the day of the Royal Procession in which he took part, evoked so much enthusiasm; and he took the acclamation he everywhere received with the quiet dignity of a strong man unspoilt by his successes and unembittered by his defeats. He speaks English better than he imagines, and in dealing with many topics in the Conference, his speeches were always short, simple and to the point. He, indeed, has that directness of speech which grasp and clear-thinking alone can give, and South Africa has been fortunate to have for her first Prime Minister a statesman of his 
intellectual width and moral courage. I should not think he was capable of negotiating a sharp political curve on any grade; but, while he would not compromise his principles, he knows the practical necessity of compromising party demands, and will content himself with a "half-way house" if he cannot get the whole way. He is proving as honourable and effective a General at the head of a political party as he was at the head of the Boer commandos. Above all, no man who meets General Botha ever suspects his loyalty to the Empire. In several speeches I heard him deliver, he dealt in words of simple but impressive eloquence with the priceless boon of British liberty and with its palladiumthe strength of the Empire. He is obviously proud of his new allegiance, and in every vote he cast and in everything he said at the Conference he showed his loyalty to the Crown, and his desire for a permanent and closer Imperial unity.

The most picturesque figure at the table was probably Sir Wilfrid Laurier. In 1892 I met him in Ottawa, and afterwards in London. The years have now completely whitened his hair, but it is still plentiful, and this ample silver adds to that look of 
refinement and intellectuality his face has always borne. $\mathrm{He}$ is still the same verbal epicure. His is choice English, picked phrase, and he seems to savour his words as he utters them. French is his language, and he pronounces the longer words of our tongue with a slight French accent and with a deliberate precision which are very agreeable. He has the grand manner-always courtly. He spoke with a greater air of assured authority than any other man at the Conference, save, of course, Mr. Asquith. He seemed to reflect in his speeches the Canadian pride in Canada's progress and her superiority in point of territory and population over all the other Dominions. At times it seemed to me that the spirit he displayed was for the occasion unnecessarily independent; but there is a directness about his style which perhaps creates or emphasises this impression. Still, both in Canada itself and in the tone and attitude of her representatives in the Conference, I recognised that Canadian nationalism is beginning to resent even the appearance-the constitutional forms - of subordination to the Motherland. Canada is developing with enormous rapidity. There is among her people a growing sense of rivalry with the United 
States, and this not unnaturally raises aspirations for nationhood free from even the terminology of an imperium in imperio. This is not a desire for separation. It is not unfriendliness to the Empire. It is mainly the stimulus of local patriotism, and of a local patriotism different in one important respect from that of Australia or New Zealand. About two-sevenths of the people of Canada are French by birth or extraction, and use French as their native tongue; of the remaining five-sevenths a very large number were immigrants from foreign lands. These people are not our kindred-they belong to a different race-they do not inherit our traditions, our national character, our loyalty. Contrast such a people with those of New Zealand-wholly British save an insignificant two per cent.; contrast the difference in the sentiment towards our Motherland this difference of origin must produce. If blood is thicker than water it is also stronger than words, and no language of loyalty can equal or produce those crimson threads of kinship, light as air but strong as steel, which unite those of British extraction oversea to the land of their fathers. As regards a very large part of her people, the loyalty of Canada is patriotism to Canada. 
Love of her as the place of their birth, and only in so far as it promotes her interest, loyalty to the Empire. Observe, I am speaking of only a section of her population. I do not forget the Canadians whose kinship with the Motherland is as close as that of the New Zealanders; but I cannot ignore, in interpreting present Canadian national sentiment, the great natural and ever-increasing influence upon it of her French community in public and private life. Whether all these considerations account for it or not, there undoubtedly seemed to me in Sir Wilfrid Laurier's words and attitude in the Conference, a certain aloofness from the family circle-a civil or rather courtly coldness to the claims of the relationship and to any proposals for a closer cooperation. Canada alone of all the Dominions represented forwarded no resolutions for consideration at our meetings; and the only one moved by Sir Wilfrid Laurier, in addition to that for the appointment of a Royal Trade Commission, was a request to the British Government to open negotiations with the several Foreign Governments having treaties with the United Kingdom, applying to the Oversea Dominions to secure liberty for any of those Dominions to 
withdraw from the operations of these treaties if they desired to do so. But my present purpose is to outline my impressions of the man, not of his politics; and there was no more impressive and striking figure at that table than he. His cast of mind is French -quick, delicate, dialectic, elusive. His prestige is already great, and prestige usually affects our judgments favourably; but if he were placed alike unknowing and unknown amid a multitude of strangers, his appearance, bearing and abilities would soon attract attention and win respect. $\mathrm{He}$ certainly is treated by British Ministers with conspicuous courtesy, even deference. So undemonstrative a man as Mr. Harcourt referred to him in open Conference as the doyen of Prime Ministers; but for all that, I am certainly safe in saying that the future of Canada and some of the policies of the Laurier Government affecting that future - notably the treaty of reciprocity with America and Canada's separate naval policy - give British Ministers more concern than the future of any of the other Dominions. 


\section{CHAPTER II}

\section{METHODS OF WORK}

I PASS now to a short outline of the methods of an Imperial Conference. These were not so much devised and adopted beforehand for the purpose as inevitably produced by the nature and form of the Conference itself. This may best be understood by recalling how these Conferences arose. The first was the Colonial Conference of 1887, summoned by the Colonial Secretary, Mr. Stanhope, and suggested by the Imperial Federation League. It was at this Conference that Mr. Hofmeyr, representing Cape Colony, proposed a scheme for promoting a closer union between the various parts of the British Empire by means of an Imperial Tariff of Customs, to be devoted to Imperial defence; but this idea made no headway. Seven years later, in 1894, a Conference of the self-governing Colonies met at Ottawa, and was attended by Imperial representatives. At this Conference cable and mail services and trade relations 
between Britain and her Oversea Dominions were discussed. It passed a resolution in favour of a Customs arrangement between Great Britain and her Colonies, by which trade within the Empire might be placed on a better footing than that which is carried on with foreign countries. This, as Mr. Sacher has pointed out, was the germ of Mr. Chamberlain's Imperial Preference; and later the first positive step to realise it was taken by Sir Wilfrid Laurier in 1897 , as a concession to the Canadian Free Traders.

The Diamond Jubilee was probably responsible for the Colonial Conference of 1897. Here Mr. Chamberlain suggested vaguely: "A great Council of the Empire to which the Colonies should send representative plenipotentiaries"; but nothing came of this, and the most important definite step taken was a resolution in favour of periodical Conferences. In 1902 our late King was crowned, and, taking advantage of the presence in London of the Prime Ministers of the different self-governing Colonies, Mr. Chamberlain arranged for their meeting in conference. Here, in a notable speech, the Colonial Secretary declared that the political federation of the Empire was 
within the limits of possibility. "Gentlemen," he said, "we want your aid. We require your assistance in the administration of the vast Empire which is yours as well as ours. The weary Titan staggers under the too vast orb of its fate. We have borne the burden for many years. We think it is time our children should assist us to support it, and whenever you make the request be very sure that we shall hasten gladly to call you to our Councils." But still the idea of political federation took no definite shape, and the main lines of discussion were those of Imperial Preferential Trade. A resolution was, however, adopted in favour of holding Colonial Conferences at intervals not exceeding four years; and 1906 was agreed to as the year of the next sitting. With the consent and agreement of all parties, however, this sitting was deferred until 1907. By this time a new British Government was in office, and at the meetings that year the late Sir Henry Campbell-Bannerman and other Liberal Ministers were present. The practice was then commenced of the Prime Minister of the Home Government opening the Conference with an address, followed by speeches in acknowledgment and reply by each of 
the Colonial Ministers-a practice followed this year. It was decided after considerable discussion at the meetings in 1902, that all later Conferences should be called Imperial Conferences, and that any matter of common interest between the Home and the Oversea Governments might be brought up and discussed-that the Prime Minister of the United Kingdom should be $e x$ officio President, and the Prime Ministers of self-governing Dominions ex officio members of the Conference; that the Secretary of State should also be a member $e x$ officio and take the chair in the absence of the President; that in addition to Prime Ministers such other Ministers as the different Oversea Governments appointed for the purpose should also be members, but except with permission of the Conference not more than two representatives from each Government should speak in any discussion. Finally, each Government should have but one vote. So far, then, as the procedure is in any way prescribed it follows the lines so agreed to in 1902. But everything connected with these Conferences, from their convention to their close, is voluntary and informal. Less formal, indeed, as far as prescribed procedure is concerned, than the convening 
and practice of a New Zealand Road Board or a Maori Council. Notwithstanding its high-sounding title of "Imperial," it has less formality and ceremonial about it than a Magistrates' Court. Canada, Australia and South Africa had each three representatives, while New Zealand and Newfoundland had two, and these thirteen men, along with such British Ministers as were present, sat round a table in Downing Street, the representatives of each Government sitting beside one another. Formality was not suggested even by the clothes worn, for, except that these all seemed uniformly well and recently made, there was here no uniformity. Some wore frock, some morning coats, and others tweed sac suits. Imperial unity was not reflected in the clothes of the Conference-these rather illustrated how informal the meetings were. Nor are these meetings any part of a political system. The Oversea Ministers have no right to attend them until they are asked. Letters are sent out by the Colonial Secretary inviting the Dominions to send representatives and forward any proposals they desire to have discussed. There is no constitutional rule or legal provision for such an invitation. There is no regular or prescribed date for D 2 
meeting. There is no obligation to attend. The representatives attending the Conference have no authority to bind their respective Governments by vote or otherwise. A resolution carried by a majority vote does not bind the minority. It does not even bind the majority. In these circumstances the taking of a vote at all seems a useless and somewhat misleading proceeding. Only to the extent to which discussion produces unanimity can any resolution be rightly said to be carried, and even that unanimity is fruitless unless it secures adoption by the Home and Oversea Parliaments. For it will be remembered that the avowed purpose of the Conference is to deal only with matters of general Imperial interest, and therefore matters arising between the United Kingdom and any particular Dominion-or between any two or more Dominions-even if important, are not proper subjects for the agenda paper. These must be left for negotiation through the usual channels.

Whether Conferences so devoid of power, both legislative and executive, can permanently justify their continuance remains to be seen. No doubt the meeting of Home and Oversea Ministers every four years for a few weeks' discussion must produce good. 
I shall later outline the results of the recent Conference. In recognition of their importance Mr. Asquith rightly said of them in a short survey : "These are all very solid and very practical results. They are results none of which could have been attainedor, at any rate, none of which could have been attained so rapidly or so effectivelyexcept by the procedure of the Conference; and when we compare the situation as it is to-day, after the experience we have had during these few weeks, with the situation as it stood when we first assembled round this table, I am perfectly certain-although many of you have come here at very considerable sacrifice-that there is not a man seated at this table who does not feel that those sacrifices were worth while. We shall all return to our respective spheres of duty with a stronger sense of our common obligations to the Empire, with a more complete confidence in one another, and with a more earnest determination to work together for the good of the whole."

But, while these general observations were justified, we may well question whether such quadrennial meetings as these can serve the purpose of any true Imperial Council capable of gradually and steadily converting 
the British Empire, which to-day hangs together partly through the forms and constitutional machinery of a past and spent Colonial system, partly through sentiment and partly through self-interest, into a systematised unity equipped for prompt and effective co-operation in all matters affecting its existence. But to this very important topic I shall refer later.

Before passing from this short reference to the methods of the Conference, I must allude to something which, while not acknowledged as one of these methods, may be roughly included among them-I refer to social entertainment. Emerson, after he visited England, said that the basis of the British constitution was not-as he had always been previously taught_- Trial by Jury," but the institution of the "British Dinner." I think the Oversea Ministers must agree with Emerson. If the success of the recent Conference could be measured by the dinners, luncheons, receptions, garden parties and dances the representatives, and especially the Prime Ministers, attended, the future of the Empire is for ever assured. A preliminary meeting of the Conference was called to settle the maximum number of invitations its members-not so much would, but-could accept; and as Mr. 
Harcourt was compiling for them a social engagement list, which provided occupation for day and night until early morning, almost all the time they would be in England, one sympathised with General Botha's pathetic protest that "really his health could not stand it." But Mr. Harcourt was inexorable. It was part of the systemevidently one of the methods of the Conference, and so the compilation went on. The kindness of the British people was boundless, and each of us will always remember the sincere, warm and generous hospitality of many a host and hostess; but so far as the entertainment was organised and arranged in connection with the Conference, it seemed to me to be rather overdone, and to suggest that the impression prevailed in Downing Street that agreement and Imperial co-operation among Oversea members could be more effectively secured by excessive hospitality than by consultation and full discussion. Even if other members of the Conference do not share this view, still all, or most of them, must agree that this daily and nightly round of entertainment was unnecessary, and not only limited the time for adequate discussion, but impaired their energies and fitness for the real work they were in London to do. 


\section{CHAPTER III}

\section{MATTERS DEALT WITH}

Now I pass on to some of the more important matters dealt with. In reviewing these, one cannot do better than follow the survey Mr. Asquith gave us at the close of the Conference.

First, as regards matters affecting the relations of the Empire, not to its constituent parts, but to foreign countries, it was unanimously affirmed that the Dominions should be afforded by the Motherland, as far as she thinks it possible, an opportunity of consultation in the negotiation for the international agreements which affect them. This concession, as yet only ex gratia, by the United Kingdom, was a significant recognition of the right of the autonomous Dominions to some voice in the Imperial policies in which they are vitally concerned. It is, however, a concession at will, and is, I presume, revocable if, and when, the Government of the day in England deem it expedient. 
Akin to this matter, because it touched international relations, was the Declaration of London, brought before the Conference for consideration. It was urged by Mr. Fisher, the Prime Minister of Australia, that the Oversea countries of the Empire should have had an opportunity of consultation before the terms of the Declaration were definitely agreed to by the British representatives. While the principle so insisted on was conceded by Sir Edward Grey, he explained the difficulties which in this case made its application almost impossible. He said : "I agree-and the Government agrees entirely-that the Dominions ought to be consulted before the next Hague Conference takes place, about the whole programme of that Conference, and this will involve their being consulted automatically with regard to everything that arises out of it." Here, again, is a wide and unequivocal recognition of a kind of partnership between the Motherland and her young nations in many matters of foreign policy. Still, it must not be forgotten that it is purely one at will. It has no constitutional force or legal obligation. It may be determined at any time. But even the concession marks the radical change which has taken place in Britain's 
Colonial policy, and clears the road for some constitutional provision whereby this favour may become a right.

The Declaration of London was really unanimously adopted by the Conference, for, although the Australian representatives did not vote on the motion for its adoption, Mr. Fisher said they commended it, and that very clearly and definitely.. The discussion upon the terms of this Declaration was full of interest, the two outstanding contributions being the masterly address of Sir Edward Grey, and General Botha's critical examination of the main objections that had been raised. Almost immediately after this discussion in the Conference closed, a similar discussion began in the House of Commons, and there can be no doubt that the strong approval of the Dominions did much to increase the majority by which the Declaration was ratified by the Mother of Parliaments.

The last of the international matters dealt with was Sir Wilfrid Laurier's motion that the Home Government should, if and when any Dominion so desires it, secure, if possible, to that Dominion, liberty of withdrawal from existing commercial treaties between the United Kingdom and foreign countries. 
This motion was carried, and although recent practice on the part of the Motherland in negotiating commercial treaties has prepar $d$ the way for such a motion, its unanimous adoption has a profound significance. Lord Salisbury deemed commercial unity throughout the Empire essential to the maintenance of Imperial co-operation, and held the view strongly that that Imperial co-operation must be abandoned if the different Governments of the Empire of their own accord decided to adopt separate systems of commercial relations with foreign powers. Hence the older commercial treaties treat and apply to the Empire as a whole, binding, for example, Canada as well as the rest of the Dominions-just as a commercial treaty with the United States binds each of the constituent States. Of recent years, however, the Home Government has, in deference to the protests of some of the Dominions, notably Canada, adopted the practice of restricting any new commercial treaty it makes to the United Kingdom alone, unless one or other or all of the Dominions desire to be included in it. Hence, now, it seems, Lord Salisbury's principle of Commercial Imperial Unity for the purposes of foreign treaty is at an end. 
The Motherland can, unless she violates the principle adopted by her practice of the last fourteen years, make no commercial treaty for the Empire. It must be limited to the United Kingdom alone, unless the Dominions desire inclusion. On the other hand, each of the autonomous Dominions is free to enter into such foreign commercial treaties as it thinks fit. It might even differentiate against the Motherland in favour of a foreign country. It is true that Sir Wilfrid Laurier, in summing up the present position, affirmed that it should be the policy of the self-governing Dominions to develop their trade as far as they can with the Mother Country, and give every facility to make it closer year by year as years go on; and, in all arrangements made with foreign nations, provide that all advantages secured by these arrangements should be given both to the United Kingdom and to all the other Dominions that comprise the Empire; but he also affirmed the principle that each of the autonomous Dominions has the fullest and freest right, without, it would seem, ever consulting the Motherland, to enter into such foreign commercial treaties as it thinks fit.

I am not in any way discussing just now 
the expediency of this from the point of view of Imperial solidarity. My purpose is merely to make clear how far the Empire has departed from that commercial unity for which Lord Salisbury strove, and which at present exists both in the German Empire and the American Commonwealth. The new principle emerged in definite illustration in the proposed reciprocity treaty between Canada and the United States. The principle may be best in the interests of the Dominions considered individually, but that it will be centrifugal, and not centripetal, in its tendencies, is surely more than probable.

Passing now to matters dealing with the internal relations of the Empire itself, I agree with Mr. Asquith in thinking that the proposed changes in the Privy Council are of cardinal importance. In the survey to which I have referred, he said: "I think in regard to the constitution and practice of our Imperial Court of Appeal the Dominions had well-founded criticisms to make, which were put forward here with moderation, but with great point and force, and I believe that the suggestions which have now received your approval will, when carried into effect, provide the Empire as a whole with a tribunal which, both by its 
composition, by the numbers in which it sits, and the procedure which it adopts, secures unanimous confidence." The Lord chancellor was present during the interesting discussion on the Imperial Court of Appeal, and gave a very clear outline of the composition and work of the Privy Council. In substance, the personnel of the House of Lords and Privy Council are identical, but as a result of the discussion the Home Government made certain proposals (unanimously agreed to by the Conference), which are to be embodied in definite shape in a memorandum to be sent to the Dominions as early as possible. These proposals will provide, first, that there should be for the whole British Empire one final Court of Appeal in two divisions, one for the United Kingdom, consisting of the same persons who are now entitled to sit in the House of Lords, and the other for the Oversea Dominions, consisting of the persons now entitled to sit on the Judicial Committee of the Privy Council, with such further additions as might be agreed upon; secondly, that that Council should be strengthened by the addition of two English Judges; and, thirdly, that the procedure in regard to delivery of judgment in this second branch should be 
assimilated to that now followed in the House of Lords. According to the present practice the Privy Council delivers but one judgment, which purports to be the judgment of the Council as a whole. The Judges of the House of Lords always ciuliver separate and sometimes dissenting judgments. It was intimated during the discussion, both by the Prime Minister and the Lord Chancellor, that if New Zealand desired it, the Home Government would provide for the appointment of a New Zealand Judge to the Privy Council, to hear New Zealand appeals, in the same way as a Canadian, Australian and South African Judge has already been appointed to hear appeals from their respective Dominions.

Next in order of importance of the matter within the sphere of Imperial law was the agreement arrived at with regard to Naturalisation throughout the Empire. At present, the conditions upon which an alien is admitted to the rights of a British subject differ not only as between the United Kingdom and the different Dominions, but between the Dominions themselves. Particularly is this so with respect to the period of residence requisite for qualification. The Mother Country demands five years as the 
qualifying period. But this is not the chief anomaly. To-day, a man naturalised in New Zealand or Canada is still an alien throughout the rest of the Empire. Thus, Americans passing over their frontier into Canada, and obtaining Letters of Naturalisation there, are still aliens in the United Kingdom - although a native of India, being a British subject in India, is a British subject throughout the Empire. The discussion at the Conference resulted in a unanimous agreement that a scheme of Imperial citizenship should be adopted, based on the following five propositions-

1. Imperial nationality should be worldwide and uniform, each Dominion being left free to grant local nationality on such terms as its Legislature thinks fit.

2. The Mother Country should maintainas at present-five years as the qualifying period; but five year's' residence anywhere in the Empire is in future for this purpose to be considered as equivalent to five years' residence in the United Kingdom.

3. That the grant of Imperial nationality should in every case be discretionary, and this discretion should be exercised by those responsible in the Dominion in which the 
applicant has spent the twelve months immediately preceding his application.

4. That an Imperial Act should be framed on these lines, and so drawn as to enable each of the self-governing Dominions to adopt it.

5. That nothing in this proposed legislation should affect the validity or effectiveness of local laws regulating immigration or differentiating between classes of British subjects.

This step, in itself of great practical use, will help the larger purpose of promoting a true Imperial citizenship.

Among resolutions of less, but still of great importance, was that by which the Conference unanimously declared the expediency of making mutual arrangements with a view to the enforcement in one part of the Empire of judgments and orders of the Courts of Justice obtained in another part, including judgments or orders for the enforcement of commercial arbitration awards. This proposal was, by a separate resolution, extended to orders made in favour of deserted wives and children against husbands and parents. At present, as the Attorney-General, Sir Rufus Isaacs, pointed out, the Dominions are regarded in law, as far as the enforcement 
there of a judgment obtained in the United Kingdom is concerned, as in practically the same position as a foreign country; similarly, a judgment obtained in, say, New Zealand has about the same effect in Great Britain or in any of the other Dominions as a judgment obtained in Germany. This is a curious conmentary upon our claims of Imperial unity, for there seems no reason why there should not be the same mutuality of enforcement of judgments and orders throughout the Empire as there is, for instance, between Ireland and England. In the discussion which took place upon this subject, the Attorney-General made it quite clear that the provisions for mutuality would contain all proper safeguards against abuse or oppression.

So far I have referred only to matters upon which the Conference, including the representatives of the Home Government, arrived at a definite agreement to be followed by definite action; but a number of resolutions were passed by the Oversea members affirming the desirability of furthering a number of important objects. The discussions upon these were treated sympathetically by the British Ministers present, but they committed their Government to 
no definite action. For instance, the desirability was affirmed of drawing the attention of the Governments of the United Kingdom and of the Dominions to the expediency of taking steps to secure uniformity of treatment to British shipping, to prevent unfair competition with British ships by foreign subsidised ships, to secure to British ships equal trading advantages with foreign ships, to promote the employment of British seamen on British ships, and to raise the status and improve the conditions of seamen employed in such ships. These desiderata were sympathetically acknowledged by the British Ministers, but were obviously regarded rather as worthy aspirations than practical proposals.

The resolution in favour of more uniformity throughout the Empire in the law of copyright, patents, trade marks, companies and accident compensation, is one which I believe will be followed by some definite collective action. The Colonial Office has already been industriously collecting material in all the Dominions for law-drafting purposes.

Good, too, will result, and indeed has, I believe, already resulted from the resolution in favour of cheaper inter-imperial cable E 2 
rates; but it is very unlikely that anything will come of the proposals for a State-owned Atlantic cable. There is, however, a cheerful prospect of a realisation of the desideratum (affirmed by the Conference) of a chain of inter-imperial State-owned wireless telegraph stations for social, commercial and defensive purposes.

The approval by the Oversea representatives of a recommendation to His Majesty's Government to take steps towards the universal adoption of penny postage is not likely to hasten that golden day for the reasons very frankly and clearly stated by Mr. Herbert Samuel, the PostmasterGeneral.

In moving the South African resolution for concerted action to promote better trade and postal communication between Great Britain and her dependencies, and restrain shipping combines, trusts and conferences, Sir David de Villiers Graaf, Minister of Public Works and Posts and Telegraphs in the Union Parliament of South Africa, delivered a very powerful, exhaustive and convincing speech, showing, among many matters of great interest, some astounding extortions under a shipping combine. The motion was adopted, but it is not likely 
any concerted action will follow. In these cases, until we get some true Imperial unity, the patient must minister to himself, and each Government must do the best with its own legislative powers to protect its people against this kind of combination and extortion.

If outspoken criticism could effect its end, the speeches delivered in the discussion upon a reduction of the Suez Canal dues should bring these charges down. We are told that the present rate is $6 d$. per ton, and that the charges upon a ship of, say, 10,000 tons for passing through the Canal are, in all, $£ 2,900$. The charges paid by the P. \& O. Company for the passage of their ships through this waterway amount to more than the total of the wages paid to the crews of the ships. So at least Mr. Fisher, the Prime Minister of Australia, told us, and his figures were not questioned. $\mathrm{Mr}$. McKinnon Wood, Parliamentary UnderSecretary for the Foreign Office, admitted that the British Government held a large number of shares in the Suez Canal, but said that so far as Britain's influence was concerned, it was always used in the interest of shipowners rather than in the interest of the shareholders, and pressure had been 
continuously employed to secure reductions in the dues. Great Britain has, however, no dominant voice on the Board of the Company, having there only about one-tenth of the representation. So the matter was left, Mr. McKinnon Wood securing a modification of the terms of the motion, which in its final shape seemed to meet his approval and ran as follows-

"This Conference is of opinion that the dues levied upon shipping for using the Suez Canal constitute a heavy charge, and tend to retard the trade within the Empire and with other countries; and invites the Government of the United Kingdom to continue to use its influence for the purpose of obtaining a substantial reduction of the present charges." Thus the net result of the discussion was the adoption of a motion of encouragement to the Home Government to continue in its present well-doing.

I have now touched upon every resolution - certainly every important resolutioncarried by the Conference save one, and that was the resolution in favour of a Royal Commission for the investigation of the natural resources and of the means of improving the trade of the Empire. This was 
the most novel, if not the most important outcome of the Conference. It may have far-reaching results, and it is interesting to see how it arose, and what is expected of it. Australia had tabled this resolution : "That this Conference, recognising the importance of promoting fuller development of commercial intercourse within the Empire, strongly urges that every effort should be made to bring about co-operation in commercial relations and matters of mutual interest, and that it is advisable, in the interests both of the United Kingdom and of the British Dominions beyond the seas, that efforts in favour of British manufactured goods and shipping should be supported as far as it is practicable." The representatives of Australia did not speak to or explain the full and definite meaning of the terms of this resolution. These terms seem to me to have been carefully and skilfully framed to raise the Imperial Preferential Tariff question, without expressly doing so. At any rate, that any discussion upon preference in favour of British manufactured goods, the promotion of fuller development of commercial relations within the Empire, and of co-operation in these commercial relations, could have proceeded without 
embarking upon the Imperial Preferential Tariff controversy, seems to me, as I think it did to every one, impossible. On this motion being reached, however, and before Mr. Fisher began his speech in explanation and support of it, Sir Wilfrid Laurier intervened. He asked to be allowed to make an observation, and, proceeding to read the motion, said that he and his colleagues were in complete sympathy with its object. He then referred to the haphazard way in which the commercial relations between the Motherland and her Dominions, and between the latter themselves, had arisen. In illustration of this, he alluded to the preferential tariff passed by the Dominions in favour of British manufactures, and urged that to pass Mr. Fisher's resolution would not lead to any tangible results. He urged that the first requisite to tangible action was more information regarding the existing trade conditions between the Motherland and the self-governing Dominions and between the latter themselves. Explaining his point, he said that the trade relations between Canada and Australia were not satisfactory. They wanted a tariff mutually preferential, but so far had not been able to achieve that end. For these reasons he asked Mr. Fisher 
to allow him to substitute for the Australian resolution the following-

"That His Majesty should be approached with a view to the appointment of a Royal Commission representing the United Kingdom, Canada, Australia, New Zealand, South Africa and Newfoundland, with a view of investigating and reporting upon the natural resources of each part of the Empire represented at this Conference, the development attained and attainable, the facilities for the production, manufacture and distribution; the trade of each part with the others and with the outside world, the food and raw material requirements of each, and the sources thereof available; and to what extent (if any) the trade between each of the different parts has been affected by existing legislation in each, either beneficially or otherwise."

Sir Wilfrid Laurier did not suggest that the scope of this Commission would include investigations into the expediency of an Imperial Preferential Tariff. The terms of the resolution did not refer to tariff, but its general object would certainly not exclude their consideration. This, obviously, was the view of both Mr. Asquith and 
Mr. Harcourt, for they asked that there should be added to the end of the motion these words-

"And by what methods consistent with the existing fiscal policy of each part the trade of each part with the others may be improved and extended." As Mr. Harcourt explained, he wished this addition made to show that the Royal Commission was not to inquire into or make recommendations on the fiscal policy of the Dominions or the Mother Country. In outlining the purposes of the proposed Royal Commission, Mr. Asquith made clearer still that it was not to deal with fiscal policies. "I think," he said, "it is important to emphasise that the proposed Commission is to be an advisory body with a reference as wide as words can make it-inquiring into all matters connected with trade, commerce, production and intercourse between the different parts of the Empire, and that it is not a Commission to suggest-still less to dictate-policies to the different Governments, either to the Government of the United Kingdom or to the Government of any of the Dominions. In regard to matters of policy, we are and must remain our own masters. Nor do we seek advice; nor would 
it be fitting for anybody outside to tender us advice in regard to large questions either of domestic or of Imperial policy." Having thus, and in another part of his speech, made perfectly clear that fiscal policies were absolutely forbidden ground to the Commission, Mr. Asquith proceeded to say that the Commission would be a peripatetic one, visiting and sitting in the different parts of the Empire, and having upon it the ablest and most representative men that can be found for the purpose.

Sir Wilfrid Laurier's proposal was unanimously adopted, and it served immediately two purposes. First, it shut out any discussion on the tariff reform question; and secondly, it gave British Ministers an opportunity of stating in the most unequivocal terms that the front door, now firmly barred and bolted by the present Government against any change in Britain's fiscal policy, is not going to be opened under any pressure or persuasion from the selfgoverning Dominions, and also that this Royal Commission was not going to be used as a side door to let in that apparently hateful heresy. But to ask a body of the most highly qualified, expert, commercial men, such as these Commissioners will be, to 
investigate and discover by what methods the trade of each part of the Empire with the rest of it may be " improved and extended," and then to add, "but you are not to consider or ascertain how this can be done by changes or modifications in the existing fiscal systems, unless they are consistent with the existing policy of the countries under consideration," is surely a little like asking an expert to find out how your business might be improved, but forbidding him to inquire into or suggest any means of improvement inconsistent with your existing business methods. But, even subject to this serious limitation upon its scope, I believe that such a body of men as is contemplated will collect information and make recommendations of great commercial value to the Mother Country and all her Dominions. They will, no doubt, interpret their powers pretty liberally, but, forbidden as they are to touch fiscal policies, Mr. Chamberlain's aim of Imperial unity upon a commercial basis of trade reciprocity is not likely to be in any way furthered by the Commission. 


\section{CHAPTER IV}

NEW ZEALAND'S PROPOSAL AND IMPERIAL FEDERATION

The most important topic discussed at the Conference was Imperial Unity. This discussion took place on Sir Joseph Ward's motion in favour of a representative Council of the Empire, and as I desire to deal somewhat fully with this question, I have reserved it for a separate chapter. It is impossible to arrive at any sound conclusions in this matter without a clear view of what our present so-called Imperial Unity consists. This can be best seen by a reference to its origin. Theoretically still, and formerly in fact as well, the United Kingdom and her Colonies formed a strictly political and commercial unity-a unity which arose from the actual, as well as from the legal and constitutional, relationship between the Motherland and her Oversea dependencies. Let us, then, remember how Britain's Colonial Empire began. She held a foremost place among the nations of the world before she 
had any colonies, and would no doubt still hold a foremost place if she ceased to have any. By migration, conquest and commerce, she has extended her rule over about a quarter of the land surface of the globe, and to-day her Empire falls into three territorial groups-

The Self-governing Dominions,

The Crown Colonies; and

The Indian territories ruled by or dependent on Great Britain as Sovereign.

It is not necessary to distinguish the different kinds of relationship to the Motherland based upon the different degrees of selfgovernment possessed by these groups. There is, of course, nothing fixed or immutable in these differences. England's modern Colonial policy is to confer local autonomy upon her dependencies as soon as the time is ripe for it, as she did years ago upon the Crown Colony of New Zealand and those of Australia. But this granting of Colonial autonomy is a comparatively modern policy. Originally all Colonies were treated as subject and tributary landsplantations, indeed, the North American Colonies were styled, with representative Government only in name. 
The affairs of the British Colonies were at first entrusted to a Committee of the Privy Council, but afterwards were transferred to a Commission created by letters patent. Later, the Council for Trade was combined with this Commission, but in $\mathbf{1 6 7 5}$ the Colonies were again placed under the control of the Privy Council. This arrangement lasted for twenty years, when a Board of Trade and Plantations was created-the actual executive work being in the hands of the Secretary of State for the Southern Department, who was assisted until 1772 by a Secretary of State for the Colonies. In that year the Board of Trade and Plantations, and the additional Secretary, were abolished, and Colonial control given over to the Home Office. Then follow some minor changes, and finally a distinct office of Secretary of State for the Colonies was, in 1854, created. It is the occupant of this office who has now officially the right of advising the veto of any Act of a Colonial or Dominion Legislature. Perhaps the difference between Britain's attitude to her Oversea possessions before the American Revolution and now can be best illustrated by reference to some of the earlier legislation she passed to control them. Until well on in the eighteenth 
century, English colonists were compelled to sell their products exclusively in the English markets, and buy their requirements entirely from the merchants and manufacturers of England. Here is a provision in one of these statutes : "No commodity of the growth production or manufacture of Europe shall be imported into the British plantations but such as are laden and put on board in England, Wales, Berwick-upon'Tweed, and in English-built shipping whereof the master and three-fourths of the crew are English."

The preamble to this statute, which effectively excluded the Colonists from every market for European produce except that of England, contains a delightful exposition of Britain's Colonial policy of that day. These exceedingly severe restrictions, we are told by the preamble, " are imposed to maintain a greater correspondence and kindness between the subjects at home and those in the plantations; keeping the Colonies in a firmer dependence on the Mother Country, making them yet more beneficial to it," and so on. This "greater correspondence and kindness"-this "keeping of the Colonies in a firmer dependence on the Mother Country," was the earlier idea of Imperial 
unity. It was unity through an utterly selfish, relentless central control in England. I do not desire to give an historical survey of changes and stages through and by which the Colonial policy of to-day has been reached; but contrast the basis of Imperial unity a hundred years ago with the basis of it to-day, as expressed by Mr. Asquith at the recent Conference. In his view it is "local autonomy-absolute, unfettered and complete - with loyalty to a common head, and with spontaneous and unforced co-operation for common interests and purposes." The basis of the one is force-if necessary-compulsory co-operation, submission to central authority; the basis of the other, at least in the view of the present Prime Minister of England, is voluntary association. But, while voluntary association may now be, in fact, the basis of our Empire, it is certainly not so in theory or in constitutional law and rule.

Notwithstanding every grant of local auto nomy Britain has made to her Dominions and Colonies, it is her Parliament alone that has sovereign power over them and over /all who reside in them. The British Parliament could, by legislation, directly limit, alter or destroy the rights of the people in the self 
governing Dominions. It can, if and when it pleases, make any statute it passes operate in the Oversea Dominions, and override any law there inconsistent with its provisions. Not only could statutes which had passed through the Houses of Parliament in any of the Dominions be prevented from becoming law by a mere alteration by the Imperial authorities of the Governor's instructions, but the British Parliament could itself revoke any powers of self-government it has granted a Dominion or Colony. On the other hand, Canada, for instance, even now has no power to alter her Constitution, however much her people desired to, while the people - and the people alone-of each State in America have this power. Again, none of the autonomous Dominions have any right to a voice in questions of foreign policy. Constitutionally, for example, there is nothing to prevent the Motherland from tomorrow ceding New Zealand, without asking the consent either of her Parliament or her people, to a foreign power. The people in the Dominions have no right to a voice in any question of peace or war. War declared by the King on the advice of his Ministers involves the whole Empire, although the Oversea Dominions are quite unrepresented 
in the House which supports and really elects those Ministers. So advised, the King alone, and without consulting any Dominion, can make with a foreign nation any treaty, commercial or otherwise, it thinks fit, although that treaty may seriously affect or even injure one or all of these Dominions. There is, indeed, only one seat for the sovereignty of the Empire, and that seat is the British Parliament, including, of course, the Monarchy. Unlike the people of the United Kingdom, the people in the Oversea Dominions have no voice in the creation of that sovereignty. They do not by their votes create the dominant factor of that sovereignty-the House of Commons-as do the people of the Motherland. In a word, we oversea are not truly citizens of the Empire. The obvious fact is that, if the Dominions have become what has been called "a galaxy of free nations"-if their autonomy is now "absolute, unfettered and complete" - the present forms and theories of Imperial government are an anachronism. They no longer correspond to, but contradict the new régime. The parental system of control suitable for small children in practice falls into desuetude as they approach or reach manhood. Constitutional theories may F 2 
grow obsolete and so pass away, but there is always some risk in this process. We are told that the self-governing Dominions have now an autonomy " absolute, unfettered and complete" - that it is upon their voluntary association the Empire rests. But if so, the will which maintains this voluntary association may terminate it. Suppose Canada or Australia desired to-morrow to leave the Empire, and become in theory and in fact Sovereign and independent States. Have they legally and constitutionally at present any right to take such a course? Plainly not. It would not only be in excess of their autonomous powers, but a complete violation of the condition upon which their autonomy was granted to them. Herein lies a danger. If, as we are doing, we create and foster the belief and doctrine that the Empire is a "galaxy of free nations" held together merely by voluntary association, we necessarily create and foster the view-soon to be considered a natural and fundamental right - that the Dominions - one or all-may go their own way as independent and Sovereign States whenever they think fit. If this freedom is intended and will be always acquiesced in by the British Government, no trouble may arise; but while constitutional 
rule and law say plainly that such separation is ultra vires, it may surely be open to statesmen who do not share Mr. Asquith's conceptions of voluntary association as the basis of Empire, to resist-if necessary by forceany such proposed separation as a violation of one of the Motherland's fundamental rights.

Let me bring this point out more clearly by reference to the history of the United States of America. Their Constitution contained no prohibition against the separation from the Union of any of the States. Hence their separation was not a violation of any rule or principle expressed in that document, and certainly not so clearly unconstitutional as would be the separation of an autonomous Dominion on its motion from our Empire. The uncertainty due to the silence of the American Constitution as to a State's right to separate was among the causes mainly responsible for the Civil War. Hence, while it is a graceful rhetorical flourish to talk about a "galaxy of free nations"-and while it flatters Colonial sentiment to be assured by England's Prime Minister that our Oversea autonomy is " absolute, unfettered and complete," and Imperial union a voluntary association, it had better be clearly recognised that this is not our 
constitutional system at all, and that it may some day result in embarrassment-to use a mild expression-to the Motherland, unless in the meantime the form of our Empire's Constitution is properly and formally brought into some kind of harmony with these new conceptions of Imperial unity. But the expediency of making any changes in our constitutional system really depends upon what future the Motherland on the one hand, and the Dominions on the other, desire the Empire to have. Both Cobden and Bright regarded Colonies as evils tending to prevent universal peace, and as encumbrances to be got rid of as soon as practicable. Both these statesmen believed that the establishment and promotion of Free Trade would have for one of its laudable results the separation of the Colonies from the Motherland. Writing in 1842, Cobden said: "The Colonial system, with all its dazzling appeals to the passions of the people, can never be got rid of except by the indirect process of Free Trade, which will gradually and imperceptibly loose the bands which unite our Colonies to us by a mistaken notion of selfinterest." Is this spirit and doctrine found in none among Free-traders in England today? I think this doubtful, although I 
admit that this is easier to say than to prove. It certainly seems that many of them would rather let the Dominions go than give their products a fiscal preference. The memories of the Boer War and of the devoted loyalty of the part the Colonies took in it, together with more recent proofs of Oversea patriotism, have created in the Motherland a widespread sentimental regard among the masses of her people for the Dominions; and while this lasts, if it is not, indeed, permanent, politicians and political leaders are apt to exaggerate the value they place upon Imperial ties of attachment, and upon the importance of its autonomous dependencies to the United Kingdom.

Doubtless there are many men in England who, like Lord Morley, a member of the present Government, take a narrow view of the true Colonial policy. Over twenty years ago, Mr. Morley referred to the rise of the Imperialistic spirit in England " as a certain reaction which events will probably show to be superficial." In his review of Seeley's Expansion of England, the present Lord President of the Council evinced his impatience with the advocates of a Greater British World State, and ridiculed Imperial federation proposals, "What," Mr, Morley 
asked in the review, " is the common bond that is to bring the Colonies into a Federal Union? Is it possible to suppose the Canadian lumberman and the Australian sheep-farmer will cheerfully become contributors to a Greater Britain for keeping Basutos, Pondos and Zulus quiet? Is there any reason to suppose that South Africa will contribute towards the maintenance of cruisers. No, we may depend upon it that it would be a mandat imperatif on every federal delegate not to vote a penny for any war or preparation for war that might arise from the direct or indirect interests of any Colony but his own."

How time turns the wisdom of the wise to folly! As Mr. Hillier, in commenting on these words, points out, "If no Federal Union has been attained, the common bond that may yet achieve it has been revealed. Canadian lumbermen and Australian sheepfarmers have stood side by side, of their own free will, contributing funds, services and lives, to the British cause in South Africa. South Africa has, notwithstanding all her quarrels, contributed towards the maintenance of cruisers. As for the mandat imperatif and the narrow parochialism which Mr. Morley imagined every Colonial to 
cherish, the deeds of Colonists since these melancholy hypotheses were evolved have blown them to the winds." I I wonder what Lord Morley thought of the spontaneous gift of New Zealand's Dreadnought! Yet these views of his are, I think, shared by many men on his side of politics in England-not, it is true, now loudly or even openly avowed, but yet as deeply embedded in their minds and as tenaciously retained as an inherited prejudice. It will be observed that these men assume that they understand and express the views of the Colonists. Lord Morley, in the words I have quoted, was not claiming to express British sentiments regarding a closer union. He was interpreting, he thought, Colonial sentiment, of which, at least at that time, he obviously knew nothing.

Mr. Morley ridicules the idea of selfgoverning Dominions undertaking burdens along with Great Britain for keeping Basutos, Pondos and Zulus in order, but yet his colleague, Mr. Asquith, declared at the recent Conference that these Dominions now shared with the Motherland a " common trusteeship-whether it be in India, the Crown Colonies or the Protectorates-of the

1 The Commonreal, p. 128, 
interests and fortunes of fellow-subjects who have not yet attained-or perhaps, in some cases, may never attain-to the full stature of self-government."

These, and many other evidences which might be readily adduced, show the difficulty of stating at all definitely or confidently the prevailing sentiment in Great Britain regarding Imperial Federation. Mr. Asquith told us in his address that-

" In the early Victorian era there were two rough-and-ready solutions for what was regarded with some impatience by the British statesmen of that day as the 'Colonial Problem.' The one was centralisation-the government, that is, except in relatively trivial matters, of all the outlying parts of the Empire from an office in Downing Street. The other was disintegration-the acquiescence in, perhaps the encouragement of, a process of ' hiving off,' by which, without the hazards or embitterments of coercion, each community, as it grew to political manhood, would follow the example of the American Colonies and start an independent and sovereign existence of its own. After seventy years' experience of Imperial evolution, it may be said with confidence that neither of these theories commands the 
faintest support to-day either at Home or in any part of the self-governing Empire. We were saved from their adoption-some people would say by the favour of Providence, or, to adopt a more flattering hypothesis, by the political instinct of our race. And yet, in proportion as centralisation was seen to be increasingly absurd, so has disintegration been felt to be increasingly impossible. Whether in this United Kingdom or in any of the great communities you represent, we each of us are, and we each of us intend to remain, master in our own household. This is, here at Home and throughout the Dominions, the life-blood of our policy. It is the articulus stantis aut cadentis Imperii. It is none the less true that we are, and intend to remain, units, indeed, but units in a Greater Unity." Later, in dealing with Sir Joseph Ward's proposal to associate the Oversea Dominions in a more definite and effective manner with the conduct of Imperial affairs, including foreign policy, the conclusion of treaties, the maintenance of peace or declaration of war, Mr. Asquith emphatically declared that the British Government would not permit its responsibilities in these grave matters to be shared by Oversea representatives as proposed, 
Assuming for the moment, and for the moment only, that these words and this attitude accurately express the feeling of the Motherland on this topic, then it is plain that she does not desire any Imperial Federation. But before discussing this, let me put in the form of short propositions what I take to be Mr. Asquith's meaning-

1. Neither centralised control nor disintegration of the Empire has any support in England.

2. That centralisation is increasingly absurd, and disintegration increasingly impossible.

3. That each of the autonomous Dominions is and intends to remain master in its own household.

4. That each is and intends to remain a unit, but a unit in a greater unity.

5. That no participation in foreign policy, treaty making, or in questions of peace or war will be permitted to the Dominions.

Now the first observation I make on these propositions is that some of the most important of them do not square with our present constitutional system. They are rather applicable to a properly constituted 
Federation. They, indeed, seem to assume that somehow, during the last seventy years, our Empire has evolved into such a Federation. Even if we must treat Mr. Asquith's language here as figurative, the figures, although presented with convincing force, are not found in the texture of our Imperial Constitution. The autonomous Dominions are not masters in their own household in the full sense which Mr. Asquith implies. They are not units at all in theory, and far from wholly so in practice. They are units in a Greater Unity, not as one State in a true Federation is, but only as one part of an Empire subject ultimately to a Sovereign Parliament it has no voice in creating, may be said to be a unit in a Greater Unity of the Empire. Let me protect myself at this point against a probable criticism. It may be said that I am ignoring the substancethe real and practical autonomy of the Dominions, and wasting words on forms, on the mere shape of our constitutional system. My reply is that I appreciate the width and fulness of this freedom of self-government as much as any one does, but I want to clearly distinguish between powers exercised by virtue of an irrevocable constitutional right and those exercised under a delegated 
but revocable authority, no matter how permanent the delegation may appear to be. The different States of the Union in America have constitutional rights of selfgovernment defined and protected by their Constitution. They cannot be revoked or interfered with by Congress or the Federal Government. But while the British Parliament alone is Sovereign throughout our Empire, we, oversea, can retain our autonomy only at the will of that Parliament. We are masters in our own household only so long as our master permits us to be. We have, it is true, the widest powers of selfgovernment; there is little or no chance of their being modified against our will; but in theory, and as far as constitutional right is concerned, we can retain them only by the leave of Cæsar-only by the concurrence of a Sovereign Parliament, which we have had no voice in electing. I know that British Colonists care very little for forms so long as they get the substance; but there is a difference, and more than a formal one, between the powers of self-government which each State in a Federation enjoys-the proper illustration of a master in his own household -and similar powers allowed to a subject State by a Sovereign Parliament. It is this 
subjection, nominal though it may seem, that is beginning to offend the national pride of Canada. Nor is it wise, in discussing this great question, to permit the filial cordiality between us and the Motherland to gloss in glowing rhetorical periods the actual limitations now imposed upon our self-government by the legislation of Great Britain and the powers of her Ministers. A short reference to these will help us to see how far we are " masters in our own household."

What, for instance, is the scope and limitations of New Zealand's self-government. We may take these as typical of our Imperial system since the other Dominions have practically the same autonomous powers as New Zealand. Until 1852, the Government of New Zealand was vested in the Governor and an Executive responsible only to the Crown. In 1852, an Act granting this Colony representative government was passed by the British Parliament. This provided for the appointment, nominally by the King, but in practice by the Imperial Government, of a Governor whose consent is still essential to any statute passed in New Zealand becoming law. The Colony was authorised, by the Imperial statute above referred to, to legislate for "the peace, order and good 
government" of this part of His Majesty's possessions. Subject to his Imperial instructions, the Governor himself decides whether he will or will not assent to a Bill, and in point of practice, in the vast majority of cases, such assent is given as a matter of course, on the Attorney-General's certificate that in his opinion the Bill contains nothing which is repugnant to the law of England, or which requires that His Excellency should withhold his assent therefrom in virtue of the Royal instructions.

But in the exercise of the general discretion conferred upon him, the Governor can refuse his assent to any Bill he thinks fit, and so prevent it for the time being from becoming law. With regard to all Bills dealing with (1) Divorce, (2) Grants of land, money, or gratuity to the Governor, (3) Currency, (4) Imposition of differential duties, (5) Matters affecting or inconsistent with Imperial treaty obligations, (6) The discipline and control of defence forces by land or sea, (7) The Royal Prerogative, and (8) Any matter to which the Royal assent had at any time been refused-they had all, prior to the month of June 1908, to be reserved for Royal assent. Under the Royal instructions now in force in New Zealand, the Governor is not expressly 
bound to require any of the Bills to be so reserved, but in practice His Excellency exercises his general discretion in reserving for His Majesty's approval any Bills he thinks fit. In certain cases, however, he has no discretion. For instance, Sections 735 and 736 of the (Imperial) Merchant Shipping Act, 1894, which relate to the powers of Colonial Legislatures, require the reservation for Royal assent of Colonial Acts relating to oversea shipping. When a Bill is reserved it is sent to England, and the British Government then decides whether or not it will override the New Zealand Legislature -that is, the will of her people-and so prevent the Bill becoming law. This, in fact, has frequently been done. Last year, for instance, New Zealand passed a Bill providing that in vessels coming to her ports the sailors should be paid the rates fixed by the Arbitration Court awards, and as an ancillary provision a further clause imposed certain stamp duties upon the shipping documents of vessels not paying such rates. This was passed by the Legislature of New Zealand to protect her sailors - most of whose homes are in that Dominion-from competition by Lascar crews in vessels trading between Australia and New Zealand. 
New Zealand Judges have, in an analogous case, declared that such legislation is within the legislative powers conferred upon New Zealand by the Imperial Act of 1852; but the Bill in question was reserved - as he was in duty bound to do-by the Governor, and from the observations made by Lord Crewe at the recent Conference it is quite clear the British Government will not permit the Bill to become law. In other words, His Majesty's assent will not be given to it. I could easily multiply illustrations of this. Since 1895 eighteen Bills - some of them of great importance-have been reserved by the Governor of New Zealand for what is practically the approval of the Home Government, and several of these have not been sanctioned.

It will be remembered that I am dealing with Mr. Asquith's declaration that we are " masters in our own household." Even in practice this statement is not, as I have shown, wholly accurate, while in theory, and in constitutional law, it is wholly inaccurate, for the British Government could, by instructions through the proper Imperial channels to the Governor, prevent any Bill passed by the New Zealand Legislature from becoming law. And while we may be quite 
sure this power of veto (vested really in the British Cabinet) will never be exercised capriciously or arbitrarily in the main field of our self-government, there is still enough scope for its bona fide exercise in respect of Bills passed by the Dominions and dealing with changes in their system of Dominion Government-matrimonial relations, merchant shipping, alien immigration, and other important subjects-to make Mr. Asquith's words rather a façon de parler than a definition in constitutional law. But the most important point to observe is that the Dominions have no voice or representation of any kind in the Government which ultimately decides whether the will of their Legislatures is to be over-ridden. They may have-and sometimes have had-their protests met by an imperious sic volo, sic jubeo. There is no appeal. The final arbiter, who is bound by no rules or precedents, is the Government of the Sovereign Parliament of Great Britain and Ireland. I think, therefore, that it must be conceded that under our present system, if the Dominions are a "galaxy of free nations," they are so mainly because the Motherland has not chosen to interfere with them, and that if the autonomy they possess is "absolute, unfettered and G 2 
complete," it is due more to her goodwill than to any defined and irrevocable constitutional rights.

Returning now to Mr. Asquith's propositions regarding our inter-Imperial relations, I observe that he rules out centralisation of Imperial control and Imperial disintegration -the one absurd-the other impossible; and as he himself propounds or supports no solution of the "Colonial Problem," we are clearly intended to infer that in his view the present Imperial system is not capable of material improvement, and that, at least from the point of view of the British Government, it had better be left alone if not treated as permanent. Now this raises two questions not necessarily connected with each other. The first is, Will the Dominions, as they reach a wealth and population approximating those of the Motherland, continue to submit to the present system? and secondly, Would not a true Federation of the Empire add to its stability and power? Even if the answer to the first question is in the negative, a Federation may not be desired or practicable. Such a Dominion as Canada, for instance, may in time prefer to substitute for the existing system-even if nothing be left of it but the emptiest forms of its 
former tutelage-a Canadian Sovereignty and Independence.

If Mr. Asquith is right in his assumption that the present system can be continued indefinitely, and that the Dominions, even when containing either severally or jointly a greater and wealthier population than the Motherland, will still acknowledge themselves as subject to a Sovereign Parliament in which they have no voice, then I admit the case for a change in our Imperial system is greatly weakened. But if he is wrong in his anticipation-if disintegration, instead of becoming increasingly impossible as he predicts, will under a continuation of the existing Imperial control become increasingly probable-if the expansion of the Dominions renders even the theory of central control distasteful, then the call for some true Federation of the Empire becomes clamant. The case of its advocates can then no longer be answered by the reply of "let well alone." Its opponents must then choose between disintegration and some form of Federation. It seems to me, therefore, essential in the first place to impartially consider whether, under the existing system, disintegration is increasingly impossible, and if not-if signs show it is increasingly possible-then in the 
next place to inquire whether a properly devised Federation of the Empire would prevent its dismemberment, and, lastly, whether, apart from any question of prospective disintegration, Federation would not be an immense improvement upon the present Imperial system.

In each of the Dominions the spirit of local patriotism has steadily increased, and with it even a spirit of national independence. Our present Imperial system is based on "Colonialism," and, as was said by a young Australian at the Press Conference held in Downing Street in 1909, "Colonialism is dead." But this growing sense of national independence is not inimical to true Imperialism. On the contrary, it is its essential prerequisite. Federation presupposes the voluntary union of independent States, and the creation by these States of a means of united action for such great common purposes as defence. Subject to provision for this united action, each State remains absolutely and truly master in its own household. Hence the American Colonies, when framing the "Articles of Confederation and of Perpetual Union" for offensive and defensive purposes, declared that " each State retains its sovereignty, freedom, independence, and 
every power, jurisdiction and right, which is not by this Confederation expressly delegated to the United States in Congress assembled." But while the growing sense of national independence, more distinctly apparent in the larger Dominions like Canada, is not necessarily a menace to Imperialism, it may in time become so if no provision is made betimes for a true Empire Federation, wherein the national independence of the Dominions can find a natural and fitting place. In the absence of such a provision, it seems to me this increasing national independence must make steadily, if slowly, for disintegration. For what does Mr. Asquith mean by "disintegration," in the speech I have quoted from? Suppose the five self-governing Dominions were to-morrow, with the consent of the Motherland, and without any scheme of Federation, to declare their absolute independence and shake off all forms of colonialism and subjection to the British Parliament-become, that is, really and constitutionally, their own masters, with powers of self-government " absolute, unfettered and complete." Would or would not that be the disintegration of the Empire? In my opinion it would. Surely the purely voluntary co-operation of five free nations 
does not constitute an Empire. If the Dominions have a freedom " absolute, unfettered and complete," and their alliance with each other and with the United Kingdom is merely a voluntary, tacit and unorganised association, determinable at will, then the existence of our Empire has become precarious indeed. Surely that would be very like an already disintegrated Empire, with its parts for the time being merely remaining in contact; and yet it is difficult to distinguish this from Mr. Asquith's conception of the Empire as, stripped of its old colonial forms, it really is to-day. We oversea are, it seems, free nations. Centralised control of us is, he says, absurd. Our right to govern ourselves " absolute, unfettered and complete" ! What, then, unites us as an Empire? The constitutional rights and powers of the Motherland? No. Any "league of unity" ? No. Community of race and language? No. For in two of the largest Dominions-Canada and South Africa - a great proportion of the population differ in origin and tongue from the people of the Motherland. What, then, in Mr. Asquith's view, is "the unifying and cohesive force" which keeps the Empire together? First, "loyalty to a common head," and second, 
"co-operation for common interests and purposes." But this co-operation is not compulsory. It is not even organised. Provision for it finds no place in the constitution either of the Motherland or the Dominions. Mr. Asquith is quite clear about that, for he says expressly that this co-operation is not only " unforced" but it is "spontaneous." Here, then, is an Empire (excluding, for the moment, India and the Crown Colonies) consisting of six free nations-the five Dominions and the United Kingdom-united entirely by voluntary ties of loyalty to a common head and by a spontaneous unforced spirit of co-operation. Assuming, then, as I do for the moment, that this accurately describes our Empire as it is, or will shortly be, can permanent stability or effective and reliable co-operation for great Imperial purposes be claimed for it? I do not think so. Loyalty to a common head is admittedly a powerful unifying force. But these glittering phrases are apt to dim the critical eye. What is here meant by a "common head"? For the most part not a man but an office. The loyalty of the vast majority of the King's subjects-that is, of nearly all those oversea who have never seen him, and to whom personally he is but a name-is loyalty 
to him as their Sovereign, with all a Sovereign's constitutional rights, powers and functions. But suppose Canada declared, or asked, and was granted, her independence as a separate nation, in name as well as in fact; then, while widespread feelings of affection would doubtless long continue for the British Sovereign, there could ex hypothesi be no longer any loyalty. Thus it seems to me that Mr. Asquith's statement of the present basis of our Empire involves a petitio principii. It is not our loyalty which creates the Sovereign, it is the Sovereign that creates our loyalty. In the language of the logicians, loyalty is an attribute, not an antecedent of Sovereignty. Unless under our system of Imperial Government the King of Great Britain and Ireland is constitutionally-de facto as well as de jure-the King of the Oversea Dominions, it seems a misuse of language to speak of their "loyalty to a common head." For if they are or become really independent States-with a freedom "absolute, unfettered and complete" -independent, that is, of the Sovereignty of Britain, then whatever place there may be for goodwill among their people towards his person, there is none, in any proper sense of the word, for loyalty to the office of 
the British Sovereign. Hence, Mr. Asquith cannot first get rid of British Imperial control by declaring the autonomy of the Dominions to be "absolute, unfettered and complete," and then invoke loyalty to the head of that control as one of his bases for a stable Imperial unity. The second of these bases is "spontaneous and unforced co-operation for common interests and purposes" between the Dominions and the Motherland. Before more closely examining the real meaning of these words, let me ask, Can a reliable, effective and permanent Imperial solidarity be based upon the spontaneous and unforced co-operation of a collection of free States widely separated geographically, differing largely in race and tongue, and pursuing fiscal and other political policies wholly different from those of the parent State, and materially different from those of each other? A priori such a basis seems hopelessly inadequate for so great a purpose. But what is this "spontaneous and enforced co-operation" and what are these "general purposes and interests" ? To begin with, there is no machinery in our Empire for united action. No common Council of any kind to agree upon and make collective action prompt and effective. The 
Imperial Conference, it is true, sits every four years, yet it has, as I have pointed out, not only no legal existence from the point of view of the Constitution of either Great Britain or of any of the Dominions, but its members have no executive powers and no authority to bind their respective States by any agreement for common and concerted action. This "spontaneous and unforced co-operation" must, therefore, it seems, depend upon the spirit moving the Dominions from time to time, and if some or all of them are not so moved-well, they do not co-operate. This surely seems a rather haphazard method of obtaining the united action necessary for great Imperial purposes. Contrast this with the system of organised co-operation found in every Federation - that of Germany and the United States, for example-and one sees more clearly its insufficiency, and begins to feel that a combination both of "the favour of Providence" and "the political instincts of our race" is required for its successful working. But how has it worked, and how is it working? Let us test this by the measure so far achieved of Imperial co-operation in the greatest of all general interests - Empire Defence. I mean, of 
course, naval defence, because the local land forces in the different Dominions are for local, not Imperial service, unless such Imperial service is volunteered by the men themselves. What has this "spontaneous and unforced co-operation" produced up to the present time in the shape of a true Imperial Navy and a real Unity of Imperial Naval Policy? Let us see. The white population in the autonomous Dominions is at this moment not less than sixteen millions, while the population of the United Kingdom is still under forty-five millions. The area of these Dominions is sixty thousand times as great as that of the Motherland. During the past four years her naval expenditure has risen from $£ 31,250,000$ for $1907-8$ to $£ 42,412,524$ for $1910-11$, and the contributions to this expenditure by the Dominions have been as follow-

Canada Nil. Australia 1907-8, £254,069; 1908-9, £259,250; 1909-10, £268,553 (excluding $£ 60,000$ on a local fleet unit). South Africa $1907-8$, 885,$000 ; 1908-9, £ 85,000$; 1909-10, £85,000. New Zealand 1907-8, $£ 42,579 ; 1908-9, £ 47,300 ; 1909-10, £ 110,000$. Newfoundland $£ 3000$ per annum. The sums so paid, distributed per head of population for the last year mentioned, work out as 
follow : Great Britain 18s. 10d., Canada nil, Australia 1s. 3d., South Africa 1s. 6d., New Zealand 2s. $2 \frac{1}{2} d$., Newfoundland $3 d$. Each of these contributions was "spontaneous and unforced." They were in no case based upon any consideration of the appropriate share of the Empire's naval burden the contributing Dominion should pay. They were voluntary subscriptions, depending for their amount mainly upon the generosity of the mood in which each Oversea Parliament or Government found itself at the time of determining the vote. It cannot be said that this method has imposed any undue burden upon the Dominions. But, while this system of contribution did not greatly relieve the British taxpayer, it at least favoured the existing principle of one fleet and one naval policy. By 1910, however, the " unifying and cohesive force" of loyalty and of "spontaneous and unforced cooperation" in naval defence took a new departure. Canada and Australia determined to have navies of their own. Canada had never contributed a shilling to the British Navy, and she was not going to begin. She would build a Canadian Navy-Canadian, too, in the strict sense, because it was an essential part of the scheme that the new 
navy should be under Canadian control, and the statute providing for its creation also provided that it was not to participate in an Imperial war unless Canada approved of that war. It was not, it will be remembered, declared in this legislation that this local navy was to be an integral part of the British Navy, with provision for its withdrawal from active service should Canada disapprove of the war. Its real separation from and independence of the British Navy was emphasised by the statutory declaration that in case of an Imperial war the Canadian Navy was not to participate without Canada's express approval.

Australia, too, has embarked upon the construction of a navy of her own, and although her Legislature has not in terms declared that these ships are to be independent of the British Navy, we are left in no doubt by the Australian Government that the control of their navy in time of peace is to be in Australian hands, and even in time of war it is not to leave Australian waters - using that phrase in a naval rather than in a geographical sense-without the consent of the Australian Government.

It is not necessary to discuss the details of any of the arrangements made between 
the Imperial authorities and these two Dominions for the purpose of securing the necessary co-operation of the latter's fleets with the British Navy. These arrangements may make the best of the new situation, but they do, and must, fall short of producing that effective naval unity which is possessed by the federated Empires of Germany and America. That this is the opinion of the best Imperial experts there is no doubt. One of the greatest of these expressed the accepted view by the formula: "You may have several fleets, but for effectiveness you must have but one naval policy. Suppose each of the five Dominions should in time have a fleet of its own, with separate control, a separate naval programme, and, above all, with complete freedom to withhold its fleet from service in any war in which the Motherland is engaged. What becomes of that first essential of naval effectiveness in a great international struggle on the seas-unity both of policy and control? But it may be said that in such an event the Dominions would recognise this essential, and place their fleets unreservedly under Imperial control. This is, no doubt, highly probable, but are the Imperial authorities to rely upon it as a certainty? Surely not, for if such reliance 
were disappointed the result might be disastrous. It seems, then, as if the strict and reliable calculations necessary in such cases will compelBritain to leave these Dominionnavies out of account in determining her naval programme, her available naval strength, and the strategic disposition of her fleets.

But this is not going towards, but away from true and trustworthy Imperial cooperation. And yet the great Dominions could scarcely, under our existing governance of Empire, be expected to pursue a different course. We are told that the creation and local control of their navies are due to the sentiment of their peoples, and a moment's reflection will show how natural that sentiment is. Canada, for instance, proposed to spend millions of pounds, involving the spending of many millions more, in building and equipping and manning her navy. Let us suppose that her proposal had been carried out, and that, after her navy had reached a substantial size, the British Government determined to go to war with a European power, and that the casus belli was not one in which Canada had any direct concern. In deciding any question of peace or war Canada has no voice. Foreign policy and the grave issues of peace or war are entirely H 
and absolutely in the hands of the British Ministry for the time being. The Canadian Government have as little right to interfere or be heard in such matters as the Government of Mexico or Peru. Thus, then, unless Canada provided, as she has done by statute, that her fleet was not to engage in an Imperial war without her approval-if, in other words, she had made it unreservedly part of the British Navy-she would be in the position of having her navy-built, equipped and manned at enormous expense, entirely by her own people-committed to engagement in a war in respect of which Canada had no direct concern, had not been heard, and had no right whatever to be heard. Such a position, unless relieved as Canada and Australia have relieved it, would have become increasingly intolerable to their people as these great Dominions increased rapidly in wealth and population, and spent larger and larger sums upon their navies. But this departure of having separate navies has a more serious aspect than that already indicated. The Laurier Government appears to be of opinion that Canada may (by some kind of declaration, I presume) remain at peace while the rest of the Empire is at war. It is clear that while the Dominions belong to the 
Empire a declaration of war by the British Government involves them all. So long as Canada, for instance, is part of the Empire, she could not, however much she objected to hostilities and withheld her navy from them, escape the consequences of belligerency. Her produce and her ships, wherever they might be on the high seas, would be liable to capture by Britain's enemy. If protected, they must in the case assumed be protected by the British Navy. Thus Canada, although objecting to the war, and strongly objecting to its consequences, would become nolens volens involved in them. Such a situation could only be relieved by Canada "hiving off" from the Empire, and getting her independence recognised by Britain's enemy. Put quite plainly, if Canada disapproved of an Imperial war in declaring which she had no kind of voiceif in consequence of this disapproval she withheld her navy from any participation in it, and in exercise of that autonomy "absolute, unfettered and complete," which Mr. Asquith assures her she now possesses, decided to remain at peace, the temptation - nay, the pressure-towards Sovereign independence, if put on no higher ground than as the price of peace, would perhaps be 
irresistible. This seems, however, but one of the natural products of our present constitutional colonial system. The growth of local patriotism and of the wealth, population and importance of the Dominions, has fostered a sense of national independence which resents being dragged at the chariot wheels of Britain's foreign policy while deniedand emphatically denied-any right to a voice or other participation in it. This feeling must grow as these Dominions are able to show, as in a few years they will, that their numbers, wealth and material risks, as well as the peril to their liberties in an Imperial war, entitle them to a potent if not an equal voice with the Motherland, in committing the Empire to such a struggle. Doubtless this right should, and would under a proper Federation, accompany its corresponding burden, and the cost of the Empire's defences be justly distributed over the Empire as a whole. But if the future of Imperial defence-which really means the future of the Empire-is to depend upon the "spontaneous and unforced co-operation" of the Dominions, how are these burdens to be apportioned and distributed ? Who but Canada and Australia will determine what navy, if any, they will each 
maintain? Who but South Africa, New Zealand and Newfoundland, will separately determine what, if any, contribution they will make towards the Imperial Exchequer for naval purposes? What kind of co-operation for Imperial naval defence is such a haphazard method as this capable of producing? You might as well expect to maintain a navy from Imperial sources by going round the Empire with a hat. But it may be that the British Government so strongly objects to any participation by the Colonial Empire in Britain's foreign policy that no contributions from the Dominions, however liberal, and whether in money or ships, would be accepted in exchange for the grant of even a proportional voice in that policy. If this is really the attitude of the Motherland, then I think all dreams of an Imperial Federation are at an end. Or again, if the larger Dominions of Canada, Australia and South Africa have now gone so far on their own independent way-have now so far developed a deep, strong and unchangeable objection to any closer relationship with the Empire than that of spontaneous and unfettered association-the vision of a true Federation is likewise an idle dream. $^{-p}$. These are questions which different impartial 
observers will answer differently. As yet no answer has been given which can in any sense be called authoritative. It is true the proposals for a Congress representative of the Empire were not acceptable to either the British or Oversea members of the recent Imperial Conference; but what was objected to was the scheme and not the aim of these proposals. Mr. Asquith, for instance, while intimating very clearly that the British Government would not agree to share their responsibility for the foreign policy of the Empire with Dominion representatives appointed under Sir Joseph Ward's proposals, prefaced this intimation by reading a memorial to himself as Prime Minister, from several hundred members of the British House of Commons, which ran as follows-

"We, the undersigned members of Parliament representing the various political parties, are of opinion that the time has arrived to take practical steps to associate the Oversea Dominions in a more permanent manner with the conduct of Imperial affairs, if possible by means of an established Representative Council of an advisory character in touch with public opinion throughout the Empire." 
Mr. Asquith then repeated his reply to the Memorialists, "that while His Majesty's Government had the strongest sympathy with any practical step in the suggested direction, if it came to anything in the nature of setting up a new political or new constitutional machine, the initial proceeding must have the unanimous consent of the Dominions themselves." This I take to mean that the British Government does not object to a scheme for " associating the Oversea Dominions in a more permanent manner with the conduct of Imperial affairs," but that it must be devised and unanimously assented to by the Dominions before Great Britain will take any action. Candour compels me to say that in the attitude just outlined, and in his general bearing towards Sir Joseph Ward's proposals, Mr. Asquith showed himself possessed of very little sympathy with any political or constitutional changes aiming at an organised and closer Imperial unity. I am sure that he, at least, left that impression upon every member of the Conference, and that it was in some measure due to this that Sir Joseph Ward's scheme did not obtain more willing and sympathetic consideration from the Oversea representatives. Why, in such a vital matter 
as this, should the Imperial authorities wait with their hands folded until the Oversea Dominions devise and unanimously agree upon some scheme of Imperial Federation? Is it not at least as much the concern of the Motherland as of her Dominions? Is it not plainly a case for mutual thought and action? If, as seems the case, the Dominions think that the Home Government and not they should take the initiative, while the Home Government thinks otherwise, we are really left to assume that-

"Lord Chatham with his sword undrawn, Is waiting for Sir Richard Strachan; Sir Richard, longing to be at 'em, Is waiting for the Earl of Chatham."

Mr. Asquith says that if the proposals amount to a new political or constitutional machine, there must be, as an initial preliminary to British action, unanimous agreement among the Dominions. This language implies that the present "political and constitutional machine" for the governance of Empire demands no action at the hands of the British Government. It ignores the fact that the present system is based on an "old colonialism" which is dead, upon machinery which is mainly a collection of 
forms and rules no longer applicable to the true Imperial relations between the Motherland and her autonomous Dominions. It forgets, indeed, that it is now mainly by ignoring these forms, which express or imply throughout their whole series Colonial subjection to Britain, and by acting as if, in spite of them, the autonomy of the Dominions were "absolute, unfettered and complete," that the present system is tolerated at all. I have already in earlier pages tried to show how far the old constitutional side of our Empire fails to fit the Imperial development of to-day. Hence those who suggest some system of Imperial Federation-or at least, to use the words of the memorial to $\mathrm{Mr}$. Asquith, "some practical steps to associate the Oversea Dominions in a more permanent manner with the conduct of Imperial affairs" -are not open to the charge of attempting to "scrap heap" a suitable, reasonably satisfactory and well-tried system in order to erect in its place "a new political or constitutional machine." They merely desire to substitute for the antiquated mechanism devised to turn the wheels of a now inanimate colonialism, some machine capable of bringing a great Empire of free nations into indissoluble union and effective co-operation. 
"Nothing in progression," said Burke, "can rest on its original plan. We might as well think of rocking a grown man in the cradle of an infant." Mr. Asquith talks as if the people who would make a better provision for the grown man are meddlesome innovators, whose scheme will be entitled to consideration by the British Government only if it comes before them recommended for adoption by the previous unanimous approval of all the Dominions. Why, unless it is intended as an additional barrier to a closer Imperial union, is this unanimity insisted on ? Surely if Canada, Australia, South Africa and New Zealand agreed upon a scheme of Federation, the mere fact that Newfoundland disapproved of it would not disentitle it to the sympathetic consideration of the British Government-surely if such a scheme were agreed upon only by the greater in area and population of the Dominions it might well be favourably considered for adoption by the Imperial authorities, especially if it contained a provision for the other Dominions to come into it later if and when they chose. In such a matter as this, Mr. Asquith, despite all his great mental powers and attainments, discloses his limitations as a statesman. $\mathrm{He}$ 
has that intellectual conservatism which distrusts aspirations and the changes and innovations requisite for their realisation. A lawyer, great both by training and natural aptitude, he has a lawyer's pertinacious adherence to tradition, precedent, timehonoured forms and institutions. Veneration for antiquity is congenial to his mind. He wants the Empire to develop along the old, well-trodden path of the past, and with him, it seems to me, the main obstacle to devising a workable federation is not so much the difficulty of the task, great though it admittedly is, as his constitutional disinclination to attempt it.

But let us look at these proposals from the point of view of both the Motherland and the Dominions. Two vital questions lie at the threshold of our consideration of any large scheme of organised Imperial unity. The first is its practicability, and the second its utility. Can it be made workable, and even if it can, will the results justify its adoption? A negative answer to either of these questions would dispose of the scheme. But practicability is a word of vague meaning. The Roman Constitution was one of the most clumsy and ill-adapted systems the world has seen, and yet through and 
under it the practical Roman built up the greatest of the ancient Empires. The practicability of a constitution-rigid or flexible -depends mainly on the people who have to work it and live under it. No people, not even the Romans, have shown a greater genius for adapting their forms of government to their needs and development than the Anglo-Saxons. They, more than any other nation, have proved that it is obedience that makes Government, not the forms by which it is called. The virtues of the British Constitution are great and many, but how much of its unbroken success it owes to the political instincts of its people may be better understood by asking how it would have worked, say, in France. Thus, then, an institution or constitution workable in one nation may be quite unworkable in another nation of different origin and political aptitudes. We, at any rate, know that whatever alteration we may make in the present Imperial system, our past history is sponsor for our making it work if it can be worked at all. The next consideration to be insisted on is that while perfect operation is impossible in any constitution, the point at which it can properly be declared unworkable is either where the results do not, 
so to speak, pay for the running of the machine, or where much better results can clearly be achieved by another method.

Applying these observations to a federation, it would not be enough to condemn it that it worked clumsily, expensively or badly. It would still justify its existence if it produced results which in value, or on a fair balance of advantages and disadvantages, outweighed its defects. And it would still more fully justify its existence if these results could not be achieved by any other discovered or discoverable method. I am premising these reflections because many hasty critics appear to think that a constitution stands condemned as soon as they prove that it works imperfectly and has serious defects. This superficial consideration is responsible for most of the wholesale condemnation bestowed on the American Federal Constitution, and yet Mr. Bryce, after a long and thorough study of that constitution, its history, operations and results, its drawbacks and defects, declares that it excels " every other written constitution for the intrinsic excellence of its scheme, its adaptation to the circumstances of the people, the simplicity, brevity and precision of its language and its judicious 
mixture of definiteness in principle with elasticity in details." And that with all its shortcomings in practice, it has "achieved the great enterprise of creating a nation by means of an instrument of Government."

I repeat, therefore, that the beneficence of its results may in a federation far outweigh any imperfection or difficulty in its operation. These reflections are intended to make clear what I mean by practicability in these proposals, and I now pass to some considerations of their feasibility. I shall first assume that both the Motherland and the Dominions are prepared to adopt, if it can be devised, some league or federation of the Empire under which, to use the words of the farmers of the American Constitution, " each State retains its sovereignty, freedom and independence, and every power, jurisdiction and right, which it does not expressly delegate" to a Council or Congress of Empire, provided an agreement can be arrived at between Britain and each of her Dominions as to the nature and extent of the powers and authority to be so delegated by each. Each of the American States delegated to and vested in Congress the exclusive right and power to control and deal with certain subjects, the chief of which were- 
(1) War and peace, treaties and foreign relations generally;

(2) Army and Navy;

(3) Federal Courts of Justice, including final Court of Appeal for the Union;

(4) Commerce and trade--foreign and between the several States;

(5) Currency;

(6) Copyright and patents ;

(7) Post Offices;

(8) Power to raise revenue for these purposes.

This is merely an illustration. The number and extent of the powers delegated differ in each of the federations which have been created during the last hundred years. In some the delegation has been less, in some larger, than in the case of the United States. The Canadian federation transfers more power to the Central Government than does the federal system of either Australia or Switzerland. The delegation may be so shaped and limited as to suit both local sentiment and Imperial purposes. For instance, the powers of the Council or Congress might be limited exclusively to foreign policy and defence. "Federations are of two kinds. In some the supreme power 
of the Central Government acts upon the communities (or States) which make it up, only as communities. In others this power acts directly not only upon the component communities, but also upon the individual citizens, as being citizens of the nation no less than of the several communities." 1 The former, the looser kind of federation, may be used by a nation as a stage on the way to the latter-the closer. This may be seen in the history of America, Switzerland and Germany. Germany was a league of States before 1866, but since 1866 and 1871 has been a national as well as a federal State. Our age has certainly been an age of great federations. Besides the federations of Switzerland and Germany and other more complicated unions in Europe, the federating principle can be seen at work in every one of Britain's great self-governing Dominions. In Canada, in the federal system of 1867 ; Australia, in the federation of 1899; South Africa, in the union of 1910. This federal spirit, strong and prevalent enough to overcome all local difficulties and weld these great but previously divided Dominions into one nation, is aspiring now at building up,

1 See Bryce's Studies in History and Jurisprudence, p. 491. 
by some similar bond, a true federated British World Empire of self-governing States, as a happy alternative to the present prospect of a number of independent AngloSaxon countries scattered about the globe, and proving once again that isolation, however self-reliant, makes still for weakness. If federation is not yet in the air, at least there is everywhere visible a national instinct to reverse the old current of disassociation which always makes for separation, and give fuller and fuller play to unity and co-operation.

But let us postpone further reference to the difficulty of devising a scheme, in order to here stress its need. Many influences and embarrassments are now forcing constitutional changes upon the Motherland. Mr. Asquith, with all his veneration for the British Constitution, has recently led-and led successfully-one of the most serious assaults ever made upon it in wresting the power of veto from the House of Lords. Further changes in the same direction are promised; but these are not the only proofs and signs that our venerable Imperial system is nearing the melting-pot. The United Kingdom, we are told by a great Liberal statesman, is still a democracy in form and an aristocracy 
in spirit, and the personnel of even the present Government does not contribute much refutation to that statement. But British institutions, including political control, are being steadily, if very slowly, democratised. The march of democracy in Britain may be embarrassed and retarded by forms and methods of government-it cannot be stopped. A million feet will eventually trample down every obstacle which will not yield to its progress. This is, I suppose, what Gladstone meant when he declared that Time was on his side. If, then, you would discern what institutions must go or what modifications must be made in them, ascertain which of them are blocking, or diverting from its proper course, the progress of democracy. Now the British Parliament has, under circumstances beyond its control, of recent years grown less, and not more democratic in its forms and methods. This has been forced upon it by the ever-increasing work it has to do. The area of government has enormously widened since, for instance, the first Gladstone administration. The idol of laissezfaire is now discredited by both great political parties. As an economic doctrine it is solemnly declared to be dead, and whereas 
fifty years ago Government interference and social state activities were political heresies, we now have Parliament engaged in considering and passing Bills providing land for the people, pensions for the aged, compulsory insurance for the unemployed, and all that varied modern legislation which seeks to cope, for example, with pauperism, sweating, and slum life, and to promote public health and reduce infant mortality. All this lay outside the pale of State action fifty years ago. A new theory of government has indeed arisen. The chief, if not the only end of our Constitution, is no longer to put twelve good men in a box and police a land of free competition. We are no longer content to let the cosmic process produce its struggle for existence, and its survival of the cosmic "fittest." We are now seeking eagerly to provide the conditions-social, economic, hygienic_-which by wisely limiting the struggle will enable us to improve and increase these "fittest." But this fundamental change in the theory of government involves an enormously increased burden upon its machinery. Consider the time really required by any Legislative Assembly for any adequate consideration of such a measure as Mr. Lloyd George's Insurance 
Bill, and yet it is but a small part of that great mass of modern legislation, classified as social, which constitutes the new load laid upon Parliament. The old machine is not only overworked-it has become unfit for this and its other great multifarious tasks. Local legislation, schools, and many matters concerning localities only, in all quarters of the kingdom; laws for Ireland alone, for Scotland alone, or for Wales, or England; national questions, social, economic and fiscal; Imperial questions-questions of foreign policy; these, and many other matters great and small, local and general, go to make up the present burden of the British House of Commons. No wonder it finds itself unequal to its load-that even by sitting, as it now does, practically all the year round, it can neither overtake its work nor perform what it does in a manner that can be called satisfactory, except by an abuse of language. The old Parliamentary machine is being choked by the excessive mass of material forced into it for production in the shape of laws. Hence the closure - "that destroyer of Parliaments" - and hence, too, its ruthless and repeated applications. All this is inconsistent in principle with the proper discharge of the functions 
of democratic government. But other and greater evils have arisen from the same causes. "The English system," Prof. Lowell tells us, "seems to be approximating more and more to a condition where the Cabinet initiates everything, frames its own policy, submits that policy to a searching criticism in the House, and adopts such suggestions as it deems best; but where the House, after all this has been done, must accept the Acts and proposals of the Government as they stand, or pass a vote of censure and take the chances of a change of Ministry or dissolution." 1 This is a very moderate if not inadequate statement of the position. The "searching criticism in the House" is usually cut short by the closure. Rigid economy of time imposes voluntary silence upon the Government followers and compulsory silence upon the Opposition. Nor, in other respects, does Prof. Lowell's picture fully show the evil he is pointing out. Increasing limitations have been placed upon private members' days and upon the ventilation of grievances by means of questions. These restrictions upon private members have increased pari passu with the power of, and Parliamentary control by

1 The Government of England, vol. i, p. 327. 
Cabinet. This is not the result of a day or of any particular Government. It is the inevitable product of the system. In 1884, Mr. Bryce, our present Ambassador at Washington, one of the most accurate and sagacious of men, wrote: "Those who note the way in which Parliament bends and staggers under the increasing burden of work laid on it, coupled with the inadequacy to secure the prompt dispatch of business, have frequently predicted that the House of Commons may one day deliver itself into the hands of Cabinet, the power of party organisation having grown so strong that the head of each Cabinet will be deemed a sort of dictator, drawing his authority nominally, of course, from the House of Commons, but really from a so-called direct ' mandate of the electors." "Reviewing part of this statement a few years ago, Mr. Bryce says : "Since that year (1884) sweeping changes have been made in the procedure of the House of Commons, which have greatly curtailed the rights and opportunities of private members while increasing the powers of the Ministry of the day. They have not, however, made the House able to discharge all, or nearly all, the work that falls on it, and it is becoming (under the new rules) 
less and less careful in the exercise of its powers of voting money." 1 But the effect, among many, of this Parliamentary metamorphosis which most concerns the people in the Oversea Dominions, if not those of the Motherland, is the impotence and unavoidable ignorance of the British House of Commons in respect of the Empire's foreign policy. It will be remembered that we oversea have no voice or right to a voice in that policy. We may, under the existing Imperial system, be committed to war, not only without our consent but without any authoritative knowledge of the causes which have led to it. And we are told by a recent thoughtful writer that "on foreign affairs the House of Commons has become virtually impotent. The Foreign Secretary need rarely appear there, need seldom answer questions, and can take the most revolutionary steps in foreign relations without seeking even the formal assent of the representatives of the people, and without troubling himself to give them full information afterwards. Since foreign policy determines in the main our naval and military expenditure and policy, this autocracy in foreign affairs virtually restricts the power of the Commons

${ }^{1}$ Bryce, Studies in History and Jurisprudence, p. 177. 
over finance, and through finance over the whole range of domestic policy." 1 We need scarcely delay longer tracing the cause of these changes. It is clear, first, that they are not a deliberate or even voluntary Ministerial usurpation of the powers of a democratic chamber, but are the inevitable product of the present Parliamentary system; secondly, that that system has produced these evils because it has been forced to do or attempt to do work, much of which, both in quantity and character, was beyond its energies and machinery; and, thirdly, that owing to the ever-extending area and activities of government and the growth of the United Kingdom and the Empire, this work, and these consequent evils, must go on increasing. A growing recognition of these grave defects and their causes has for some years been impressing on thoughtful minds in Britain the need of a radical change in our constitutional system. The first desideratum is to reduce the centralisation of government in respect of many matters which are purely local in their character, to take from the shoulders of the House of Commons much of the work which is of concern and interest only to

1 See J. A. Hobson's The Crisis of Liberalism, p. 9. 
some part of the United Kingdom, and relegate it to provincial Councils or a National Parliament in Ireland, Scotland, England and Wales. This would enormously relieve the burden of the Imperial Parliament and leave it free to do, promptly and well, the true work of such a Parliament - that is, the greater problems which vitally affect either the United Kingdom generally or the Empire as a whole. This, it is believed, would confer a double blessing-a blessing on the local communities or national divisions of the United Kingdom, and a blessing on the Empire universally, for it would not only have for the latter the advantages of a Parliament possessing full time and energies for Imperial matters, but it would stimulate the interests of the people in the national divisions in the affairs of their own localities, enable them to solve and settle their local problems, follow their own lines of progress, and promote generally such policy as best suited their needs and harmonised with their own energies, customs, racial instincts and aspirations. It has been often pointed out that in all civilised government the more power is given to the divisions which compose a nation, whether these divisions be great or small, and the less 
power is centralised in some body representative of the people as a whole, the fuller will be the liberties and the greater the energy of the individuals who compose the nation. Of this truth Britain's Colonial Empire is a shining and conspicuous example. Although its Dominions have no voice in any Council of the nation, they have been granted by the Motherland the widest powers of self-government, and, largely in consequence of this, the enlightenment, liberties and collective energies of their peoples are nowhere in the world excelled.

This delegation to local or National Parliaments within the kingdom known as "Home Rule all round" is undoubtedly growing in favour with the British people. The letters of "Pacificus" in The Times, in October 1910, reflect pretty faithfully the minds of a great many Unionists towards this proposal. The Liberals seem still more fully impressed with its prudence. In September of 1910 we had the Chief Government Whip - the Master of Elibank-using the following significant words in a public address : "Let them, therefore, whether they be Scotchmen or Welshmen, continue to preserve and encourage the national spirit, for who knew but that in the evolution of government, 
and with the increasingly heavy responsibilities thrown upon the Mother Parliament, the time was not far distant when (as in the English-speaking Commonwealth across the seas) both Saxon and Celt, both Scots and Welshmen, might be called upon within our shores and under a party system to give free exercise to the genius of self-government with which Providence had so highly endowed them." This utterance, somewhat cryptic though it be in form, is plain enough in meaning; but Mr. Lloyd George, addressing the same meeting, used language as downright and unequivocal as it could be made. He boldly foretold the day when they would have "a Wales independent and free, fearing God and fearing none other." Nor is Mr. Lloyd George the only British Minister in favour of " Home Rule all round." Sir Edward Grey, whose counsels in the Cabinet must be of the weightiest, believes that Home Rule must be given to Ireland, and if so it must be given to the other national divisions of the kingdom as well.

In the month of August, 1910, the Scottish National Committee issued to the "people of Scotland " a manifesto signed by twentyone Scottish members of Parliament in favour 
of national self-government. The Young Scots' Society has since joined forces with the Scottish National Committee, and I inquired and was assured that the majority of the Scottish Liberal members (many of whom I was privileged to meet) are now in favour of Home Rule for Scotland. That this movement is being accelerated by the near approach of Home Rule for Ireland is beyond question. Some men not very well disposed towards Home Rule for Ireland, but recognising its inevitability, feel that in justice to Scotland, England and Wales, they too, in the event of its grant to Ireland, must have self-government. The justice of this view is based upon considerations which have the closest relevancy to Imperial Federation. Ireland, it is proposed, is to have a Parliament of her own. She will then be autonomous, like New Zealand-taking that Dominion merely as an example. She will, also like New Zealand, be under the sovereign control of the British Parliament, for the Sovereignty of the Empire is to remain where it is at present. Is Ireland, then, to have a Parliament of her own, with representatives in the Imperial Parliament, or is she, like New Zealand, for instance, to have no representation whatever in an 
Imperial Parliament ? It seems quite clear, under the proposals of the present Government, that Ireland is to have both kinds of representation. Irish affairs will, by a change in the Constitution, be removed from the control and jurisdiction of the House of Commons, and be entrusted to a new Irish Parliament to be created by means of an Imperial statute, just as the Commonwealth Parliament of Australia and the Union Parliament of South Africa were in recent years created.

To give Ireland, then, a separate Parliament of her own, and also representation at Westminster, while denying the same privileges to Scotland, Wales and England, would for obvious reasons be unjust. Hence we may discern three forces in the political field, making for Home Rule all round. First, those who, satisfied that the Mother Parliament is entirely unequal to her tasks, seek a delegation of local affairs to local Legislatures; secondly, the Irish Party who, strenuously fighting for Home Rule for Ireland, are forced by the dictates of consistency to support Home Rule all round; and thirdly, those who, favouring neither Irish Home Rule nor Home Rule all round, but recognising the former to be inevitable, 
are, from motives of justice, throwing in their lot with the advocates of the latter. Thus, then, sooner or later it seems certain that the British Constitution is to be radically altered. Four National Parliaments will then be created answering the national divisions of the United Kingdom, for we can for the purpose of this local self-government probably rule out of our anticipations the heptarchical plan, or any artificial divisions of the kingdom into groups of countries. What powers will ultimately be vested in these national legislatures cannot yet be definitely determined, but the Imperial Parliament, we may be sure, will be left with affairs chiefly, if not solely, general or Imperial. A further ultimate question will be whether the constitutions of these National Governments is to be alterable at the will or with the consent of the Imperial Parliament, or whether they are, as in the case of the American States, to be placed outside the powers of the Central or Imperial Parliament altogether, and the right of altering them vested exclusively and for ever in the hands of the people of each of the four national divisions. If, as seems most probable, the latter course will be taken, then a written constitution for the Imperial Government as well as for the self- 
governing- unit of the kingdom will be necessary. But if these Constitutions are created-you have converted the Motherland into a federation in fact whether you use that name or not. But if she is to have such a system-if she is to consist of four autonomous countries, each with its own Legislature and each represented in a truly Imperial Parliament, with the powers in each case prescribed by a written Constitution, why not extend the system and federate the Empire? Give each of the Dominions a Constitution safeguarding (as they are in no way safeguarded now) their rights of self-government from control or curtailment by the Imperial Parliament and vesting the permanent and exclusive control of these rights in the people of these respective countries. In other words, make these Constitutions square, as they do not now, with Mr. Asquith's description of their autonomy, and make it really "absolute, unfettered and complete." That done, provide for a real Federation of the Empire by admitting representatives, not only from each National Division of the United Kingdom, but from each Dominion, to a true Imperial Congress.

I know that such a scheme is easily classed 
as visionary. Mr. Asquith would call it a hopeless aspiration, for though he sees with eagle-eyed clearness what is within his horizon, it is limited by the fact that his point of view is the plain rather than the heights. Mountainous difficulties are not impassable to a mind elevated enough to see beyond them. Every great project of federation has, at first, seemed and been loudly called visionary and chimerical. An Australian Commonwealth was once the "idle poetic fancy" of Sir Henry Parkes; an African Union, a few years ago, was ridiculed as a human impossibility, as, sixty years earlier, was the Federation of Canada. What, again, were the prospects of a German Empire when we past middle life were boys ? To any one looking around him then, on the level ground, the prospect of such a federation seemed shut out by a wall of insuperable difficulties, and yet, what a magnificent imperial unification has been achieved by the Germans in half a century under bold and far-seeing statesmanship. Union federated and effective has lifted Germany to the proud place of the greatest of the European powers, with probably even the hegemony of Europe not beyond her reach. She certainly has never failed through craven fears of being 
great, nor have her statesmen found the word " impossible" a ready answer to her imperial ambitions. But what of the work accomplished in the federation of the American Colonies some 123 years ago ? What a labour of Hercules that task presented! The perplexities, obstacles and discouragements confronting Washington and the Convention which met at Philadelphia in $\mathbf{1 7 8 7}$ were surely as great as those which beset our Empire Federalists to-day. They, too, over a century ago, in their great aspiration for unity were "dreamers of dreams," their scheme declared "the mad project of visionary young men," their work a fatuous effort to convert golden visions into iron realities; but, undeterred by the derision of cold - very cold - common-sense, they laboured on, and the result was surely a monumentum aere perennius. At this time, and amid our faintheartedness before the great problem of Imperial Unity, it is well to recall the difficulties these men met and fought and overcame. Mr. Bryce tells us, " It is hard to-day even for Americans to realise how enormous those difficulties were. The convention had not only to create de novo on the most slender basis of pre-existing national institutions a National Govern- 
ment for a widely scattered people, but they had, in doing so, to respect the fears and jealousies and apparently irreconcilable interests of thirteen separate Commonwealths, to all of whose Governments it was necessary to leave a sphere of government wide enough to satisfy a deep-rooted local sentiment, yet not so wide as to imperil national unity." 1 Well might Hamilton say " the wide establishment of a Constitution in time of profound peace by the voluntary consent of the whole people is a prodigy to the completion of which I look forward with trembling anxiety." 2 Well might he quote the words of David Hume, "To balance a large state or society, whether monarchical or republican, on general laws is a work of so great a difficulty that no human genius, however comprehensive, is able by the mere dint of reason and reflection, to effect it. The judgment of many must unite in the work-experience must guide their labour; and the feeling of inconveniences must correct the mistakes which they inevitably fall into in their first trials and experiments." 3 The Convention,

1 See Bryce's The American Commonwealth, vol. i, p. 29.

${ }_{2}$ The Federalist.

3 See Hume's Essays, The Rise of Arts and Sciences. 
consisting of fifty-five of the ablest men these Colonies could produce, sat for nearly five months. Notwithstanding their untiring industry and patience, their patriotism and sincerity of purpose, the task before them often seemed impossible. Regard for and insistence upon the conflicting interests of the larger and smaller estates, the difficulty of devising provisions for their respective representations in the federal system, split the Convention into sections; the spirit of local independence, fostered and fomented by their recent desperate struggle for freedom with the Motherland-of-freedom - intenser far than it is even in Britain's autonomous Dominions to-day-resented limitations for any purpose. The Colonies had much more reason to fear a central authority than we oversea now have, and this naturally produced a suspicion of a plan of federation which in any way exposed their autonomy to invasion, even by a congress of the States as a whole. These, with many other impediments due to jealousies and diversities of local sentiment, seemed at times during those anxious five months to place the necessary agreement beyond human reach, and Benjamin Franklin, despairing of man's efforts to that end, devoutly proposed that 
they should seek by prayer the aid of God. But patriotism, patience, and a sagacious toleration of mutual differences triumphed in the end, and provided us with what " is perhaps the most successful instance in history of what a judicious spirit of compromise can effect." Tantoe molis erat Romanam condere gentem. But the difficulties I have outlined by no means complete the siege of troubles that beset them. Mr. Asquith, during the discussion in the Conference upon an Imperial Federation, seemed to feel that the distances that separated the different parts of our Empire were a bar to any federal system. He distinguished the federation then proposed from that of the United States upon the ground that these States were, at the time of their Union, "ring-fenced." But for federal purposes the test is not the distance between the parts or their geographical unit or contiguity, but facility and rapidity of communication. It often took as long for members of Parliament to get from Dublin to Westminster as it does now for visitors from Montreal to reach London. If Ireland's geographical position one hundred years ago offered no bar to the Union, would Canada's distance from England to-day be any bar to a Federation? At the time the American 
Constitution was passed communication, both by land and sea, was slow and difficult. Steamers and railways were not yet invented, the cable and the telegraph were unknown. It took as long to travel by land from Charleston to Boston as it took then to cross the ocean to Europe. These were undoubtedly additional difficulties in the way of federation, and yet, although it must have taken some members of Congress longer to reach Washington than it now does for our mails from New Zealand to reach London, the Federal houses were able to meet as prescribed and successfully discharge their functions. If difficulty and uncertainty of communication, if time occupied in travel from the outlying parts to the centre are insuperable obstacles to an Imperial Federation, then why, for years before there was steam, telegraph or cable, did the American system work so well? In point of fact that great Commonwealth is no longer "ringfenced." It has, for instance, distant possessions in the Philippines, while in the Pacific it has the Hawaiian Islands. If and when the Hawaiian group, now so rapidly increasing in white population, is admitted to the Union as a State, the 6,000 miles of sea and land travel which will separate the 
new State from Washington will not be felt a serious embarrassment. But if distance between the Oversea Dominions and the heart of the Empire is so great an impediment to some federal system, how is the Imperial Conference convened in London so easily? To that are called, it must be remembered, not private members of Oversea Legislatures, but the Premiers and other Cabinet Ministers of the Dominions. It is true they meet only every four years, but it is generally admitted that this is too seldom, and that if the system is to continue, the meetings must be held oftener. During the interval of four years between the last two Imperial Conferences, a Defence Conference of Oversea Ministers was called to London. So that Dominion Ministers have, in fact, during the last four years, assembled in the Empire's metropolis on Imperial business no less than three times. I suggest that if the Ministers of these Dominions, with all their local duties to perform, can so attend in London, surely members representative of these Dominions, and elected exclusively for that purpose, could come to a true Imperial Council as often as would be necessary. Is it not, indeed, quite clear that with all science has now done for expedition and comfort of 
travel, and for rapidity of communication, this objection to an organised unity of the Empire-the distance separating its partsis not a serious but merely a make-weight difficulty? I admit that if the advantages to be achieved by a Federation were small, then this time and distance question would be important, if not conclusive. But once it is seen and conceded that great and incalculable gain to both the whole and its parts would result from organised unity, objections based upon the relative geographical positions of these parts sink into insignificance. Thus, then, I come finally to a consideration of what the gain to the Empire of a Federation would be. Does such a system, let me first ask, offer any permanent benefit to the Motherland ? The area of the United Kingdom is 121,000 miles; that of the self-governing Dominions seven and a quarter million square miles, while, as I have already pointed out, the Dominions contain three-fifths of the whole Empire. The total population of these Dominions is already nearly equal to what that of the United Kingdom was when the battle of Trafalgar was fought, and in thirty or forty years their population will almost certainly exceed that of the Motherland, Is it of any vital importance to her 
that these vast areas, already so largely peopled with her own race and so rapidly increasing in wealth and numbers, should be united with her in one world-wide federated Empire, or can she afford to let them go their own way to sovereign and separate independence? The most vital of all questions for her to-day, is : Can she permanently, throughout the years to come, hold her present position among the world powers if her Dominions "hive off" and cease to be part of her Empire? Least of all do I desire to be a prophet of evil, but could any son of the Motherland, contemplating such Imperial disintegration, view without apprehension the recent rapid expansion of her powerful European rival-Germany? "Greatness is nothing," said Napoleon, " unless it is lasting," and Britain's permanent greatness cannot be assured merely by making substantial progress-she must outstrip her competitors. The race is not to the swift nor the battle to the strong-but to the swiftest and to the strongest; and the permanence of her international supremacy demands a sufficient rate of progress to maintain her lead of rivals now challenging that supremacy. Does a comparison between the recent rates of progress of Great 
Britain and Germany leave us with undisturbed equanimity? Does it satisfy the Motherland that throughout the years to come, without any aid from her self-governing Oversea Empire, she can maintain unshaken her splendid position amongst nations ? In other words, does the recent growth of her rivals enable her to contemplate with complaisance a possible disintegration of the Empire? To justify my answer to these questions I will present a few figures. They deal with the relative progress of the Motherland and Germany, taking the latter as her greatest European competitor.

I do not, however, propose to enter upon a detailed statistical comparison between the growth and products of these two countries; we have had that sort of thing recently ad nauseam, and much of it is in the field of controversy and dispute. I wish merely to impress some significant and incontrovertible comparisons. The most vital of these is in respect of population. Britain may be still the wealthiest of lands, but, as Hamilton in America and List in Germany pointed out long ago, wealth without security of continuous productive power may, so far from being a guarantee of national stability, be even a danger to it. Capital-wealth- 
may become a country's master, not its servant. She may begin to live more upon her interest than her industry. To a large extent England is becoming a residential country-a "Rentier Staat"-as a German professor calls her, composed in the main of men living on the proceeds of wealth already acquired. To-day, the people of England draw in interest or profits from foreign and Colonial investments not less than 90 millions sterling a year. Time has not disproved the poet's view of what happens where wealth accumulates and men decay; and the chief test of a Western nation's progress and continuous productive power is what has been called the movement of its population. Bearing this in mind, we turn to the depressing figures Mr. John Burns furnished the Conference during the discussion on British Emigration. In 1906 the total number of emigrants from the Mother Country was 194,6\%1. In 1910 this number had risen to 233,944, and taking the returns for the first four months of the present year as a basis, 300,000 emigrants will leave the United Kingdom in 1911. Thus, it seems certain that 60 per cent. of the whole natural increase of her population will this year emigrate from the shores of the Motherland. 
As Mr. Burns significantly pointed out, " but for the saving in life represented by a lower death-rate, and a much lower infant mortality, this emigration would be a very heavy drain on the United Kingdom," a truth he impressed by pointing out that in ten years the total increase in the population of Ireland and Scotland combined was only 210,000 , or less than the total emigration for one year (1910) by 24,000 , and less than the estimated emigration for 1911 by 90,000 . With these figures before us, we were scarcely surprised to hear during further discussion that the population of Scotland would this year, in all probability, for the first time in her history show no increase, but, on the contrary, a serious decline. Mr. Burns need hardly have added, as he did, that " with a diminishing birth-rate the Motherland could not safely go beyond 300,000 emigrants a year." "The Dominions," he said (on Mr. Fisher's motion for the encouragement of British emigrants to British Colonies rather than to foreign countries), "were entitled to have the surplus (of the parent State's population), but they must not diminish the " seed plot.' They could absorb the overflow, but they must not empty the tank." Mr. Burns's reference to the diminished death-rate and 
reduced infant mortality have an even fuller significance, when we find that even in England and Wales "the rate of increase of population has been nearly stationary since 1890, for the effect of the fall in the birth-rate has to some extent been masked by the considerable fall that has taken place in the death-rate during the same period. The death-rate, however, cannot be expected to decline indefinitely. Death cannot be prevented, it can only be postponed, and if the fall in the birth-rate continues the natural increase of the population must also diminish." 1

Now let us look at some comparative figures. Taking the ten years' period from 1897 to 1906, the annual number of emigrants from Germany never exceeded 33,824, or at the rate of 6.4 per 10,000 , while in 1906 it stood as low as $4 \cdot 3$ per 10,000. Go back, however, to the 'eighties and we find that German emigration frequently stood at a rate of over 20 per 10,000. In 1908 only 19,880 emigrants left the Fatherland, being 11,816 less than in the previous year. Thus, while in 1907 our Motherland lost by emigration 235,392 of her sons and daughters out of a total population of 44 millions, 1 See Daily News Year Book, 1911, p. 121. 
Germany, out of a total population of 63 millions, lost only 31,696 , and even that number was reduced the following year to 19,880. What wonder, then, that the people of the German Empire are now increasing at the rate of some 900,000 souls per annum, and, what is far more important, is keeping practically the whole of them within their Fatherland; while Britain, with an annual increase of only 500,000 , is losing three-fifths of this to the Dominion and foreign lands -the net result being, if the present movement continues, that the people of Britain's greatest rival are increasing over five times as fast as she is.

It is not necessary to discuss here the main causes of this, but Baron Speck von Sternburg is probably right in ascribing it, as far as his country is concerned, to "the extraordinary economical development of Germany during the last decade, the consequent steady improvement of the social status of its labouring classes brought about by the progressive rise in wages, and in the elimination thereby of what were the strongest incentives to emigration in former days." 1 To these reasons should certainly be added the fact that the German land

${ }^{1}$ See Article in North American Reviero, May 1906. 
system tends to keep on the soil a far larger proportion of the people than does that of Britain. There is a better subdivision than in the United Kingdom, where, out of a population of 45 millions, 2,500 men own more than half of the total area of the land.

One would scarcely expect to find a country losing, as our Motherland is doing, the best-or at least much of the best-of her people to increase her production or productivity; and $\mathrm{Mr}$. Collier collects and sets out in a clear and convincing fashion an array of figures, which I shall not repeat in these pages, to show what has been happening to Britain's material progress. "Figures," he says, " are of small valueas dry bones-but clothed in flesh and blood they become personalities. These figures (quoted) mean that England's wealth has increased by no more than her population; it has remained stationary, in short; while in the rival country-Germany, it has increased by 60 per cent. British expenditure must go on increasing for Army and Navy and Education if for no other reason than as a defence against war and commercial invasion. These figures, therefore, present a problem that cannot be laughed away. As we have said before, not to go ahead is to 
fall behind, and England, for the first time in her history, is falling behind." 1

If, however, there may be some controversy and disputes regarding the growth or decline of Britain's wealth, there can be no doubt that her loss of population under her present conditions and Imperial system raises grave misgivings as to her future. Mr. Burns frankly says that the safety of the Motherland will not permit her to lose more than 300,000 a year of her people or, in other words, 60 per cent. of all her natural increase. I should have thought that under existing conditions, and looking to the growth in numbers of her great European rival, she could not really afford to lose anything like so many. Surely it is not enough for Britain's lasting greatness merely to maintain the "seed plot." Surely to be content with the contents of the present national "tank" is rather a humiliating contentment. But when Mr. Burns says, "with a diminishing birth-rate the Motherland cannot safely go beyond (a loss of) 300,000 emigrants a year," he cannot, and doubtless does not, overlook the fact that if Britain's annual loss by emigration has increased from 109,000 in 1890 to 300,000 in 1911 , there is no decree of

${ }_{1}^{1}$ England and the English, pp. 78 to 132. 
either Man or his Maker against this increase continuing. Are there any visible or reliable reasons for its not continuing ? The increase may be more less rapid, but if it continues at all, with a declining birth-rate and a deathrate which science cannot appreciably further reduce, then Mr. Burns, far-seeing man as he is, must be filled with forebodings for the future of his native land. Now all this seems to me to stress still more emphatically the need of a true Imperial Federation. What has the Empire already lost by emigration? Ask what land many of the millions of the United States of America have come from, and add to these the thousands, if not the millions of the sons and daughters of Britain who have sought a new home in foreign lands. All these, now under a new allegiance, are liable to be called upon to fight for a foreign flag. It is estimated that if the men and women who emigrated from the United Kingdom to live under the Stars and Stripes (to say nothing of those going to other foreign lands) during even the last fifty years had gone to Britain's Oversea Dominions, the total population of these Dominions would be to-day greater than it is by 20 million souls. In other words, if these emigrants had been kept 
within the Empire, the Oversea Ministers at the recent Imperial Conference would have represented some 36 millions of British people-a population equal to that of England and Wales at the present time. Need we pause to consider what this loss is to the Empire? Happily, British statesmen have in recent years come to recognise the wisdom and the need of directing the great stream of emigration flowing from the Motherland to countries under the British flag. No man has done more in this direction than Mr. Burns himself. So recently as 1900 the proportion of this stream that found its way to the Oversea Dominions was only 33 per cent., while 67 per cent. passed from the Empire to foreign allegiance. By 1906 these percentages were altered to 54 and 46 respectively, while last year, of the total volume of emigration from the United Kingdom, 68 per cent. was kept within and only 32 per cent. settled outside the Empire. This year the returns so far show the Empire is to get 80 per cent., and if so, of the 300,000 who will probably leave the Motherland, only 60,000 will change their allegiance. This, it must be admitted, is a vast improvement, and it is largely due to the excellent and increasing work in the right direction carried 
on by the now admirably organised Emigrants' Information Office and its agencies throughout the kingdom. But what will it avail the Motherland if she so generously gives in quantity and quality her life's blood to her daughter States oversea, if the family is not united as one great household, under willing but enduring bonds?

Suppose this contribution, already too generous, were to increase so as to absorb all her natural increase-no violent stretch of the imagination-would the distribution of this life's blood among the Dominions leave the Motherland, under our present Imperial system, as strong as a world power after the distribution as before? Surely not. Canada already declares by statute that her navy is not to engage in an Imperial war without her consent, while her statesmen declare that she is entitled to remain at peace even if the Motherland is in a European struggle. And those who would resent this must remember, as I have more than once pointed out, that the people of Canada have no right to any voice in the grave Imperial issues of peace or war. They are not, in fact, citizens of the Empire. Let us penetrate that silvery haze of patriotic generalities and poetic descriptions of our Imperialism which 
has gathered around the reality, and see what our Imperial system really is. The Dominions are without a voice in foreign policy and without obligation to help the Motherland either in preparing means of defence or in war itself. They might, in her hour of peril, refuse to contribute to her aid in men, money, or ships. In exercise of their freedom, "absolute, unfettered and complete," they could, especially if Mr. Asquith is right, look on with folded arms at the Motherland in a death struggle. This is to all - at least to most of us-unthinkable : -but what our parent State must realise is that while the sentiment upon which her Imperial system is now based would surely bring her aid, that system would as surely still leave that aid entirely dependent on the "co-operation spontaneous, unforced," and, let me add, unorganised, of the Dominions themselves. Hence, while it is surely wise to direct the emigration of her hundreds of thousands to lands within the Empire, it is as surely true that under our present system of Empire their departure even for her own Dominions leaves the Motherland much weaker for their loss.

Now contrast this with what happens under a true Federation. The millions who 
have migrated from the Eastern to the Westward States of America-though many of them have had to travel to their new homes as far as from Great Britain to Canada -still remained within the Commonwealth. They reached their destination as fully and completely its citizens as when they began their journey. They had still, through the ballot-box, the same voice in its Federal Government as they had in their eastern home, and while they took with them this and other rights of citizenship in a great union they also took with them the duties of citizenship, and among these the fundamental duty of defending the union by pocket, personal service, or, if need be, by the sacrifice of life itself. Hence, it matters nothing to America's strength as a nation what migrations of her people take place from the old parent States to the younger Western ones. The Federation binds them all into a true unity, and every man, wherever he may be in the lands of that great nation over whose head the Stars and Stripes floats, owes it the same service and obligations. Would that the same could be said for our Union Jack, for it seems that though the Motherland may unhappily one day be in the throes of war, there is no 
obligation upon the millions of British subjects in her Oversea Dominions to come to her aid. But the Motherland must be prepared to give them the rights before she can expect them to bear the burdens of Imperial citizenship, and these rights can only be workably conferred by means of some suitable federation.

I shall refer later to some of the definite advantages of such a scheme for the purposes of Imperial Naval Defence. But one important and lasting benefit of Imperial Federation-still from the Motherland's point of view-is apt to be overlooked. It seems generally recognised that Home Rule all round is an essential preliminary to such a Union. This would, of course, mean self-government for Ireland-Ireland, " that lovely lonely bride whom Britain wedded but has never won "-and self-government for Ireland would remove, or at least enormously reduce, potent influences against that fullest amity which should stand between the two great English-speaking nations on the eastern and western sides of the Atlantic. "What is politics?" asked a Chicago boy of his father. "Politics in America, my son, is a choice of Irishmen." And although this reply has its main point in State and 
Municipal politics, it not unfairly suggests the extent of the Hibernian influence upon the general government and policy of America, especially in her international relations with England. It is easy for Englishmen to allow a natural sense of national pride to underrate the advantage of winning the goodwill of the Irish Americans, but no friend of the Motherland who has been much in the United States is likely to underrate it. But by the grant of Home Rule to Ireland the goodwill would be won, not only of Irishmen in that great Commonwealth of the West, but of Irishmen throughout the Colonial Empire and, indeed, throughout the World. How many millions of strong men and women all these comprise, and what their warmer friendship for Britain would mean, we need not delay to consider here. The point I wish to make at the present moment is that British statesmen could, if they chose, make the solution of that most pressing of domestic problems-national self-government-within the United Kingdom the basis of a great, new, organised Imperial system. But what advantages does such a system offer to the Dominions? Let me mention the minor ones first, and the all-important ones later. All are agreed that many prac- 
tical objects could be attained or promoted by some form of closer union.

First, there are the great interests of international trade and commerce. These embrace much more than fiscal questions. They include the vital and urgent need of safeguarding the welfare of British shipping throughout the Empire; its promotion and protection, and some agreement as to the limitations which may be properly imposed upon it in the different Dominions for the purposes, for instance, of protecting local seamen from competition with Asiatic crews, and of restricting alien immigration. Our merchant shipping is of incalculable importance, not only to our progress as an Empire, but to our safety. During the last fifty years the number of British persons employed in the home and foreign trade has declined. During the same period the number of foreigners employed in British ships has enormously increased. But, although British shipping has increased, that increase is far behind the increase which, during the last ten years, has taken place in the foreign shipping entered and cleared at the ports of the United Kingdom. We must aim at being as exclusively as possible our own international carriers, and this and the other objects 
I have named demand the co-operation of Imperial Union. Such a Union could also promote an improved system of postal, telegraph and cable communication within the Empire; better and more expeditious transit for men and merchandise, a settlement in Common Council of the difficult and now often unsolvable questions of proportional contribution to a necessary shipping, cable and other subsidies, an Imperial scheme of emigration, an Imperial coinage, while a uniform system of weights and measures would also be important work for some body really representative of the Empire. At present there is no uniformity in the systems of either coinage or weights and measures, but the most inconvenient diversity in both. In 1878 the German Empire adopted and made compulsory the metric system, and the United States made it a compulsory system in 1907. We are told that the British Empire and Russia are now the only two great powers outside the pale of civilisation in this matter. Mr. Fisher, the Prime Minister of Australia, tried to impress consideration of this system upon the Home authorities at the recent Conference, but got no encouragement.

A great field for useful Imperial co-opera- 
tion is that of uniformity of commercial legislation. It is difficult to over-estimate the immense advantages which might be reaped in such a field. Here, again, the Germans have given us an admirable lead. Is there any doubt that their excellent and uniform code of law dealing with trade and industry has contributed to her great commercial and industrial development, and helped on the greater end of German unity. This excellence and uniformity were not attained without time, patience and imperial co-operation. Let us consider an illustration of the advantages of unity and uniformity in this class of legislation. You can in America, with the expenditure of not more than $£ 100$, obtain for a new invention letters patent operative in all the States and throughout the whole Commonwealth of nearly 100 million people. To get the benefit of an invention throughout the British Empire requires twenty-eight separate grants of letters patent, at a cost of some $£ 600$, while to secure Imperial protection for a trade mark necessitates between thirty and forty registrations. This does not seem to disclose any conspicuous degree of unity in our Empire. A representative Council could do splendid work in constructing an Imperial code of commercial 
law dealing with patents, trade marks, copyright, public companies, partnership, bankruptcy, marine insurance and many other branches of legislation. Of course, the differences demanded by differences of local conditions would be weighed and regarded, but Imperial scope could with immense advantage be now given to a mass of commercial law in a well drafted code. I am attempting no exhaustive list of matters which might be referred to a Council really representative of the Empire. I am merely giving illustrations. But, great as is the importance of these matters, they probably would not alone justify an Imperial Federation. Some better system of voluntary conferences than we have at present might probably serve the purpose of the Common Council they require, although such conferences would be, even in these matters, a far less prompt and effective machine than a Federation would supply. It is when we come to foreign policy and the defence of the Empire, that the utter inadequacy of voluntary Imperial Conferences for their main purpose is seen, and the need arises for some body elected by or in some way really representative of both the Motherland and the Dominions. Compared with Foreign Policy, Imperial Defence and War, 
all the great and important matters of general interest I have already outlined sink into insignificance. The relationship is that of the smaller affairs of our existence to the final question of life or death.

"Territories," runs a favourite motto of one of Britain's great rivals, "are for the nations who can take and hold them." Force is still the final arbiter between the world powers, and it is only by its ability to hold and defend its own that our Empire lives and moves and has its being. But are we as a nation sufficiently impressed with what Imperial Defence really means to us? We repeat glibly the well-worn truth that our guarantee of peace is our readiness for war, and ostensibly treat the latter as the price of the former. But the value we really place on anything is what we are prepared to pay for it, and if we judge from the complaints we hear regarding the burden of our defences we may well doubt whether we fully realise the inestimable boon the price secures us. It has been often noticed that a longcontinued peace - an extended immunity from the horrors of war-almost invariably produces in a people a grudging spirit towards expenditure upon armaments and a declining respect for the soldier and his 
profession. England has shown this more than once during the last hundred years, and it has required war or the imminence of war to rouse her to a sense of the value or insufficiency of her defences. Then for a time she has lost her indifference. Then it's "pay, pay, pay." "And it's Mister Tommy Atkins when the drums begin to roll." But in point of fact, England has never had brought home to her in all its ghastly reality what the exchange of peace for war is. She has never had a foreign foe within her shores, and the last battle fought by her own sons on English soil was that of Preston, 196 years ago. Contrast this with the experience of such countries as Germany and France. Time and again in the past their fields have been stained with blood; their towns in foreign occupation, and their people-millions of them living to-day - witnesses of the grim horrors that take place when men meet men arrayed for mutual slaughter. The sea and her navy have saved Britain from these bitter and indelible memories, and prevented the growth of that militarism and military spirit which self-preservation has largely forced on some Continental nations - notably Germany, where considerations of national safety have rigidly subordinated individual 
freedom to the needs of effective armaments and armies, and habituated her people to burdens of taxation and military service which they have borne the more readily because they have known more fully than we what war really is.

I will not pause here to show that, on the one hand, these divergent lines of national experience have made us a peaceful people, or, on the other hand, how much the military -if you will, the aggressive military-spirit of Germany has been produced by her situation, and by the perils which have threatened her frontiers. These reflections are intended merely to mark the fact that the British people have never (like the Germans) had burnt into their memories the real difference between peace and war, or been taught by the humiliation of foreign occupation what sacrifices a nation must be prepared to make for national defence. But if this is generally true of their kindred in the Motherland, it is particularly true of the British people in all her Dominions save only, in a limited sense, those in South Africa. It is hard for the Australians or New Zealanders to picture what a great struggle between our Empire and one or more European powers would mean to them. They have no memories of 
such a thing in the past to help imagination to foresee its grim results. Of this at least we may be certain, that if the Motherland were crushed and beaten, their plight, both during the conflict and after it, cannot now be adequately conceived. I will not speculate upon the prospects of cession or annexation. What would happen, for instance, to Australia or New Zealand after the supremacy of the British Navy had been destroyed, and the supremacy on the seas of that of some foreign nation established, is not a contingency one cares to dwell upon, but the loss, even during the struggle, to these Dominions, in their trade and commerce alone, would surely be appalling. To Canada and South Africa it would probably be at least as great. We frequently hear it said in the Dominions that with the efficient citizen forces they are now providing for, no foreign power could send men enough to land upon their shores and take permanent possession. This is probably true, but its truth does not establish their safety. Suppose the British Navy were crushed and Britain forced by starvation into a capitulation involving the cession to the victorious power of, say, Australia or New Zealand; would it be necessary for this power to take forcible and effective 
possession to force these Dominions into submission? Surely not. It is true neither of them could be starved into it, but in the absence of all naval protection for their shipping, their trade (imports and exports alike) with the whole outside world could be practically completely stopped by the enemy's ships of war. What this isolation would mean is hard to conceive. How long these Dominions could or would withstand such a calamity is a question the answer to which must be wholly conjectural.

The protection of the Imperial Navy has so long been given to the Dominions practically free, gratis, and for nothing, that, like many other great continuous and costless blessings, it has, until recently at least, been regarded by them rather as a natural righta permanent maternal duty imposed by nature upon the Motherland towards her children. Again, the naval protection the Dominions enjoy, being, as it has been, so long potential rather than actual, is vaguely perceived and inadequately appreciated. We are apt to think that a law backed with full power of enforcement is of no use when there are no transgressors. This may, however, be the greatest proof of its efficacy. England has supported her policy of peace 
by the greatest navy afloat, and what the world owes that navy for its now longcontinued international peace and order cannot be calculated, for, be it remembered, the brotherhood of man does not bulk big in foreign policies. International hatred is commoner than goodwill, and international jealousies commoner than either. Far removed from the centres of European politics, it is the more natural that the Dominions should inadequately appreciate what they owe to the peace-preserving potentialities of the British Navy. This comfortable illusion that their naval protection is wholly the natural duty of the Motherland is disappearing, but has not yet quite disappeared in the Dominions. There has, during recent years, however, grown up in them as they have left infancy far behind them a feeling that it was time they took a share in the Mother's titanic navy burdens. No common scheme of any kind, however, has yet been adopted for fairly distributing these burdens, and, in my judgment, none short of an Imperial Federation can provide effectively the requisites of such a scheme. These include efficient machinery, first, for the distribution and discharge of the burdens; secondly, for that complete co-operation and co-ordination of 
all Imperial defences so essential to their full strength; and thirdly, for conferring upon the Dominions the corresponding rights of Imperial citizenship to which the discharge of the duties of that citizenship entitles them.

But before passing from the consideration of such a scheme from the point of view of the Dominions, I desire to emphasise the fact that the United Kingdom cannot, under the present system, and in view of the growth of foreign navies, supply or be expected to supply adequate protection for our more distant ocean highways. The more the commerce of the Dominions grows the more must its sea protection be increased. Who is to supply this increase? Surely not the Motherland alone or practically wholly. Small local navies may furnish some defence in territorial waters, but on those ocean highways along which the trade of every Dominion must travel the Imperial Navy alone can give safety to our merchantmen. Can this be disputed ? I have not yet met an advocate of local navies who had the courage to contest it. But is the present Imperial Navy, in the event of a great war, capable of adequately protecting these highways? This is at least doubtful, and hence 
the strengthening of that navy becomes a plain policy of prudence for the Oversea Dominions. In whose power really at the present moment are the China seas and the Pacific? Certainly not in the hands of England, and it requires but a feeble effort of imagination to enable us to foresee in what peril our Dominion commerce on these waters would be placed in certain possible contingencies. He jests at scars who never felt a wound, and if the gravity of present and prospective international situations does not impress us with the need of collective action, it is because we overseas have not yet tested the bitterness of a great maritime struggle or of having our commerce-perhaps even our shores-at the mercy of an enemy. Thus, then, the closer Imperial unity I am urging on the Dominions is not intended to appeal merely to a self-sacrificing filial affection for the Motherland, but rather to their own self-interest-to motives of security, self-protection, and even self-preservation. In this connection, moreover, it must be borne in mind that national development does not depend upon the nation alone. You may have brought your fields to perfection-to yield the best fruits and flowers, but if your fences are thrown down and your 
cultivations trodden under the feet of a horde of men or beasts, your labour has been in vain. What profits it that these younger Dominions have with pains and thought and patience erected a social and economic system which has spread comfort, enlightenment and true freedom throughout their lands if they pass as the spoils of war to some iron-heeled masters, who ruthlessly sweep that system away, or to some swarming nation whose myriads flood the defenceless shores of these British countries with men of wholly different blood and civilization? Hence, as the Dominions prize their liberty and the laws and institutions which place them in the van of human progress, they must be prepared to make sacrifices to permanently protect from foreign foes the land in which these blessings have had their birth.

But there is another, if less important, aspect of closer unity. Thesentimental advantages involved in making her children overseas true citizens of the Empire should not be ignored by either the Motherland or the Dominions. Mr. Chamberlain, in impressing the fact that "the day of small nations had passed away and the day of Empires begun," urged us to think imperially, for the sense M 2 
of greatness keeps a nation great. But, could anything teach the people of the Dominions to think imperially so effectively as Imperial citizenship ?

The voice they possessed in the control of the Empire might be-would be if each of them were taken separately-insignificant; even if taken collectively it would for many a day yet be far from the dominant one; but having a voice at all, the mere participation in Imperial government would surely stimulate in the lands oversea a sense of unity with the Empire and of national greatness which no far-seeing Empire-builder should ignore.

I hesitate to even touch the thorny topic of Tariff Reform, but no outline of the advantages to the Dominions of a system of Imperial Federation should omit a reference to the fiscal difficulties and differences which now impede the development of trade within the Empire. I know how firmly and emphatically we oversea have been told by the present British Government that the free trade policy of the Motherland cannot be departed from to provide any Imperial preference, and for the purposes of the observations I wish to make here I will take this statement as final. But even if 
Britain's rigid adherence to free trade is to be permanent, there would still be ample scope for a Congress or other continuous Council representative of the Empire to promote inter-Imperial trade. It could further commercial reciprocity between different Dominions, and induce them to make such reciprocal fiscal changes as would be to their mutual benefit. Moreover, through common counsel and by taking joint action with the Motherland, trade routes could be opened up, shipping and other subsidies agreed upon, and the shares in which these subsidies should be contributed by the whole country and each Dominion determined. I have already admitted that this is work voluntary Conferences could do, but I maintain that it is work a properly established representative Federal Council could do far better. One final comment, in this connection, I should like to make, and I express it by adopting the words of Mr. Borden, when Leader of the Opposition in the Canadian Federal Parliament. "It is apparent," he said in 1910, "that some great project of co-operation in trade within the Empire must soon be undertaken. The Empire is entirely unorganised in this respect." 
So far I have in the barest outline sketched some of the advantages of Imperial Federation from the points of view of the Motherland and the Dominions respectively, but their interests in this matter are not different or divided. If under some representative system of Empire these fifteen millions of white people overseas were to contribute ten shillings a head (I am naming that figure quite haphazard and merely for illustration) as their contribution to Imperial Naval Defence, the eight millions sterling so produced would not only provide their trade on the High Seas with additional protection, but, by strengthening the Imperial Navy, give additional security to the Motherland, and thus to the whole Empire. In this connection, the growth of the Dominions in point of population becomes very important. The net increase, after deducting emigration, in the people of the United Kingdom is now about 200,000 a year; that of Germanytaking a great Continental nation for the purpose of comparison-is 900,000. That of the British self-governing Empire as a whole is over half a million souls a year.

Thus, under such a system as I am advocating, as the population of the Dominions continues to grow-as it does now-with 
great rapidity, their contributions to Imperial Naval Defence would correspondingly increase, an increase justified by the fact that their trade, growing with their numbers, would demand an ever-wider naval protection on the seas.

Now I return to the feasibility of such a scheme and, if feasible, to the prospect of its adoption by the Motherland and the Dominions. A federal system is not a stereotyped form of government. It may be moulded and adapted to suit the circumstances and peculiarities of the Empire to which it is being applied. Much or little power may be left to the federal authorities-that power may be restricted by conditions and limited, if desired, to but one great matter, such as defence. The world has already seen a number of mutually jealous and discordant States brought into unity by means of a federation. We have seen the German Empire pass through the stages of its Zollverein-its Bund-to its modern federal union, uniting Prussia, Bavaria, Saxony, Württemberg, Baden and Hesse, and many other Grand Duchies, Duchies, Principalities and free Cities into one of the strongest and most consolidated Empires the world has ever seen. Each 
of these States had, and still preserves, its own local government and has a separate constitution. These constitutions differ materially. Religious and racial differences stood in the way of the union; some of these States are mainly Protestant, some mainly Catholic, but under the guidance of strong and far-seeing statesmanship they sunk animosities, overcame all difficulties and emerged from the weakness of loose association to become by closer unity the greatest military power in Europe. They achieved this by adapting a federal system to suit their circumstances-and not their circumstances alone-but also the sentiment of their different peoples for local autonomy. They created a Federal Government and vested in it exclusively all questions of foreign policy, international relationship and defence. They went further and gave the Central Government control of the Empire's fiscal policy; and in this way Germany has become a united Empire, with a solidarity and power to-day unparalleled among the world's nations, and with a prosperity and progress unsurpassed except by that of the other great federation of America. I know that some efforts have been made in England to devise a scheme for closer Imperial unity. 
These have been sincere if unambitious. The plan of Imperial organisation elaborated in 1905 by able men, under the chairmanship of Sir Frederick Pollock, was a useful beginning. Mr. Lyttelton, the Colonial Secretary, submitted this with some variations and additions to the various Dominions for consideration, but a change in the Home Government took place and the new Cabinet seemed to shy at a scheme which appeared to have some dangerous affinities to Tariff Reform, since it sought the same final purpose of Imperial unity. At any rate, that purpose has not been advanced during the last six years. Indeed, developments have during this period taken place oversea, especially in Canada, which must embarrass the movement for unity, and some thoughtful men once hopeful of its achievement now think the day of its chances is past. At least it must be admitted that no real effort has been made on the part of the present Government to further this movement. The attitude of Mr. Asquith towards it at the recent Conference reflects the attitude of his Cabinet throughout their term of office. In my judgment, that attitude is due partly to objections to the principle of Federation, but mainly to political expediency. The 
framing and examination of proposals for Imperial Unity must involve consideration of fiscal reciprocity, and this in turn embraces the great party question of Tariff Reform. Thus the elaboration and promotion of a scheme for uniting the Empire under a Federation, however slender, might give-I think it probably would give some fresh impetus to the Tariff Reform movement, and the apprehension of this is, I believe, one main reason for the cold reception Sir Joseph Ward's proposal for a Representative Imperial Council received by British Ministers at the recent Conference.

I shall be reminded that there the other Oversea Prime Ministers refused to support that proposal, but that certainly does not dispose of its principle. The objections expressed by these Prime Ministers were to the scheme suggested, not to its principle. As General Botha expressed it : "They are all deeply anxious to bring the different parts of the Empire together as closely as possible." Even Mr. Asquith said that his Government had the strongest sympathy with any practical step in the direction suggested, but he proceeded to show how platonic that affection was by intimating that if the plan involved any new political or constitutional 
machine, "its initial proceeding must have the unanimous consent of the Dominions" before it would be considered by $\mathrm{His}$ Majesty's Government. My belief is that a large majority of the people of both the Motherland and the Dominions desire a closer and properly organised union. No real attempt has yet been made to stimulate this desire or give it definite expression. The problem of devising a workable and satisfactory scheme is one of profound difficulty. I recognise with Mr. Asquith that " it is much easier to express an abstract aspiration in favour of closer political union than to translate that aspiration into practical terms," but schemes of Empire are not produced by spontaneous generation, and aspirations such as that which animated the American patriots during the five months they so heroically devoted to the framing of their Union would have remained but abstract aspirations still if their fervour had been no greater than that which Mr. Asquith displays for Imperial unity. That unity we shall never get unless, fully satisfied of its desirability-nay, its need-the statesmen of the Motherland sincerely devote themselves to promoting and securing it by every means in their power. The people of both the 
Home Country and the Dominions require to be educated as to its meaning, purpose and advantages. A scheme might be elaborated by a body of chosen experts, as was done in the case of the American and of every other Federation extant. These men should be representative of the whole self-governing Empire. It might take them weeks, months, or even years to devise the constitutional machinery, overcome or meet objections, and produce at least some substantial agreement, but it would be a great work worthy of great minds. Should they fail, then at least we as a nation could feel that in this matter we had through them made a genuine and great effort to succeed, and even failure would be useful in dissipating many misleading illusions we now have as to our present Imperial unity. If, however, they succeeded in framing and agreeing to a scheme, it could be submitted in the usual way by referendum to the people of the Motherland and to each of the constituent States to be included in the Federation, and the opinion and desires of the Empire in connection with the proposal be thus definitely ascertained.

It is hopeless, if some closer organised unity is really desired, for the Motherland to 
expect the Oversea Dominions not only to take the initiative in devising a scheme but to secure unanimity among themselves before the Motherland takes any hand. Unless His Majesty's Government will actively participate both in the initiation and promotion of the scheme, we overseas may as well abandon ourselves to that contentment with the present which is but another name for resignation, for a final perception that our hopes and aspirations are for ever denied. But if political expediency induces the present Government to mark time before this problem, it is equally true that political expediency accounts for a good deal of the zeal for Imperial unity their opponents exhibit. The latter are for the most part tariff reformers, and in the Union of Empire movement they expect assistance for their cause. Thus, this great problem of unity, which, like defence, should be a supreme national and not a party question, has become embarrassed by being mixed up with the political interests of contending parties. It is largely regarded from the point of view of party advantage. While it is so regarded it can scarcely make any progress. I know how difficult it is, under existing circumstances, to secure a truly Imperial and 
substantially non-party spirit in dealing with this great matter; but if a due appreciation of its vital importance to the Empire can be impressed upon the British nation, political leaders will find it necessary to rule it out of party warfare and impartially approach it as their greatest Imperial problem. We are not in want of reminders that we must not force the pace of great constitutional changes. There is little fear of that folly among British people. They yield slowly to the force of new ideas or the need of changes in their system of government, and this disposition has done much to give them strength and stability as a nation. But there is a great difference between forced marches and aimlessly marking time. If raw haste in constitutional changes usually means delay, if not disaster, inaction before an urgent necessity for these changes is equally imprudent, if not perilous. But I know how readily some people condemn as futile what is not instantly practicable, and what little patience these will have for a scheme which can be elaborated and made workable only, if at all, after many a baffled effort and many a month of deliberation, study and dispiriting labour. Nevertheless, my faith is great that those so engaged would 
not be " sitting in darkness hatching empires vain," but would crown their great task with the glory of success. Let the Motherland show she really wants a closer alliance with her children and it will come. Let her statesmen feel and say with her poet-

"Remote compatriots, wheresoe'er ye dwell, By your prompt voices ringing clear and true We know that with our England all is well : Young is she yet, her world-task but begun! By you we know her safe, and know by you Her veins are million but her heart is one."

If British statesmen will approach the problem of Imperial Unity in this belief and spirit, the necessary response by the Dominions will not, I believe, be wanting. 
Richard Clay \& Sons, Limited, GRONBWICK BTREET, STAMFORD STREKT, S.E. $\triangle N D$ BUNGAT, SUTFOI.K. 


\section{UNIVERSITY OF CALIFORNIA LIBRARY BERKELEY}

Return to desk from which borrowed.

This book is DUE on the last date stamped below.

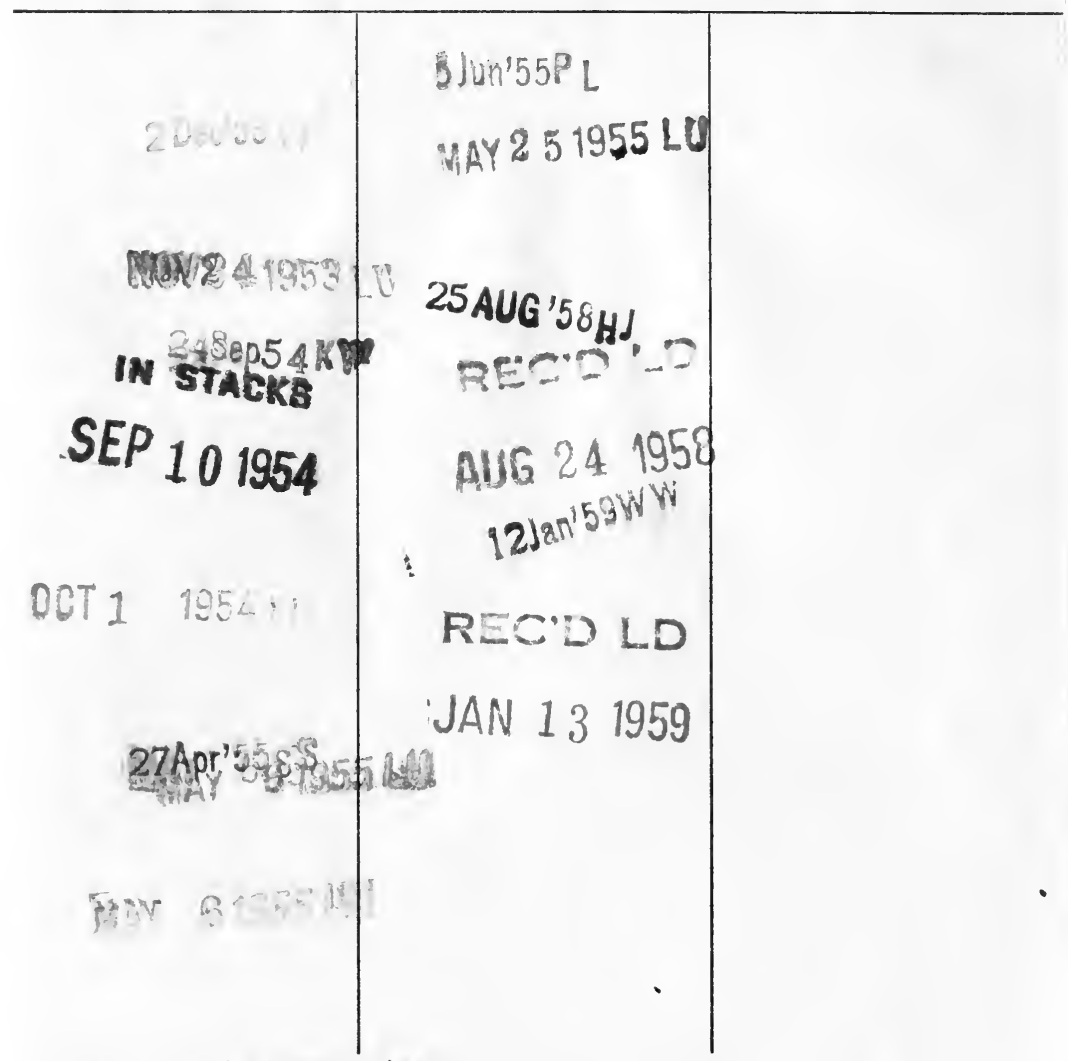

LD 21-100m-7,'52(A2528s16) 476 


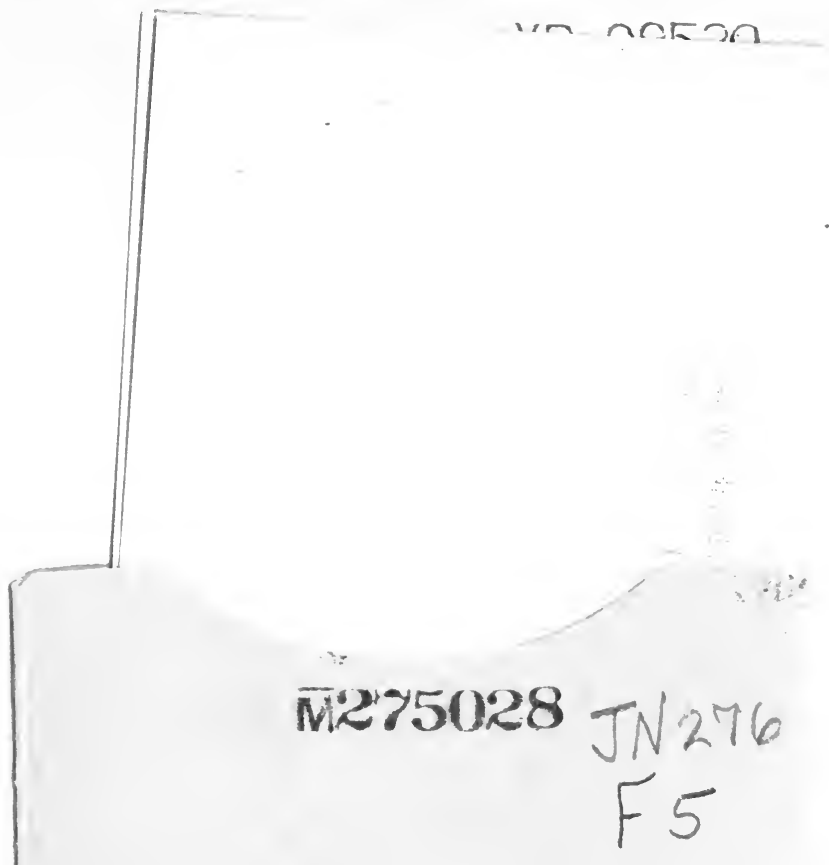

THE UNIVERSITY OF CALIFORNIA LIBRARY 


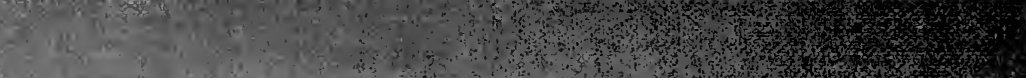

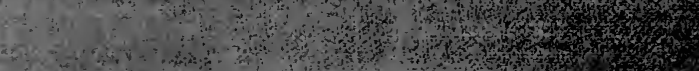

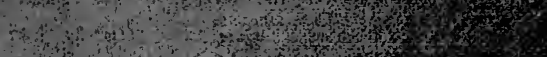

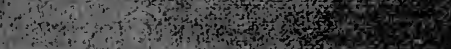

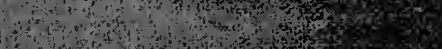

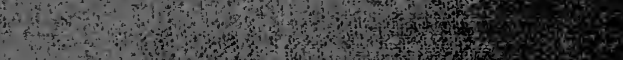

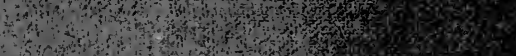

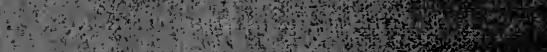

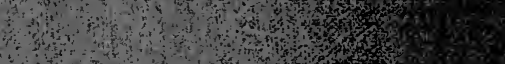

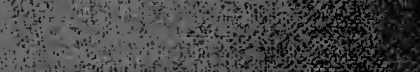

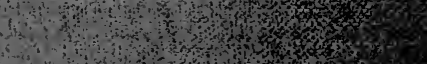

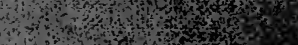

$x_{1}$

4 and

H.

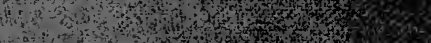

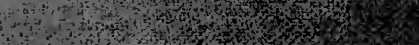

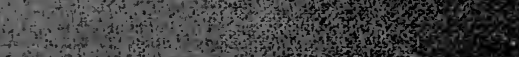

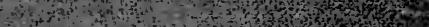

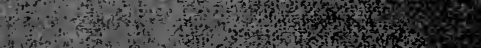

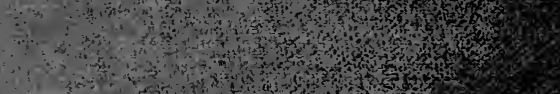

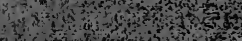

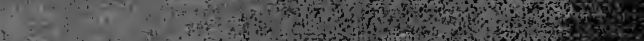

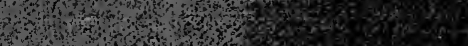

Hown

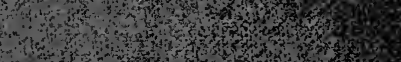

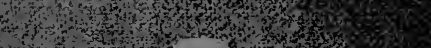

410 and

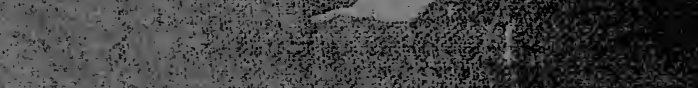

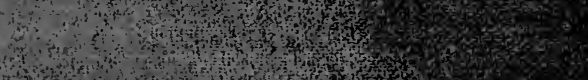

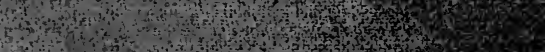

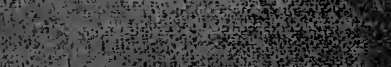

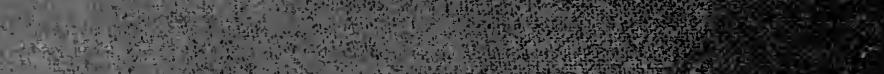

-

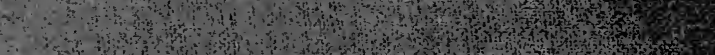

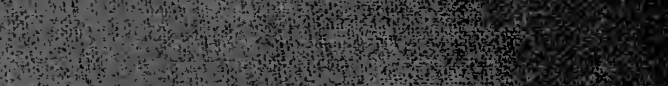

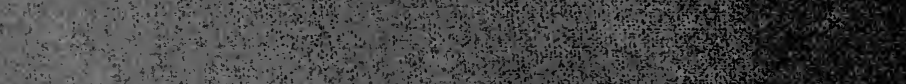

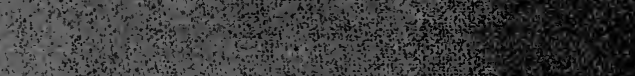

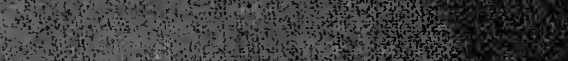

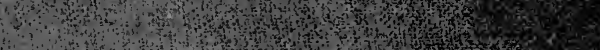

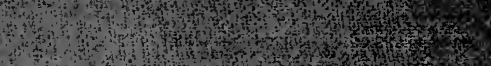

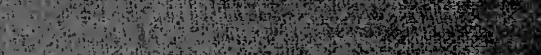

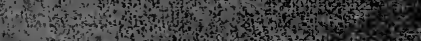

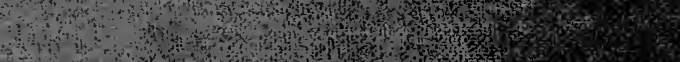

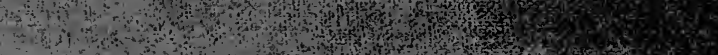
1.

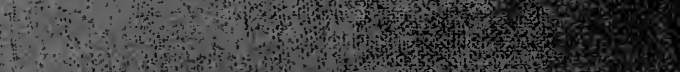
in 